\title{
1 MET targeting: time for a rematch
}

2 Jonas P. Koch ${ }^{1,2}$, Daniel M. Aebersold ${ }^{1,2}$, Yitzhak Zimmer ${ }^{1,2}$, Michaela Medová ${ }^{1,2}$

$4 \quad{ }^{1}$ Department for BioMedical Research, Inselspital, Bern University Hospital, and University of

5 Bern, 3008 Bern, Switzerland.

$6 \quad{ }^{2}$ Department of Radiation Oncology, Inselspital, Bern University Hospital, and University of

7 Bern, 3010 Bern, Switzerland.

9 Corresponding author: PD Dr. Michaela Medová, Department for BioMedical Research,

10 Inselspital, Bern University Hospital, and University of Bern. Murtenstrasse 35, 3008 Bern,

11 Switzerland. Phone Nr.: +41316323565. E-mail: michaela.medova@dbmr.unibe.ch

13 Conflict of interest statement: The authors have no conflicts of interest to declare.

14 Running title: MET targeting in cancer

15 Funding: This work has been supported by the Werner und Hedy Berger-Janser Stiftung (grant to 16 M.M.). 


\section{Abstract}

20 MET, the receptor tyrosine kinase (RTK) for hepatocyte growth factor, is a proto-oncogene involved in 21 embryonic development and throughout life in homeostasis and tissue regeneration. Deregulation of MET

22 signaling has been reported in numerous malignancies, prompting great interest in MET targeting for cancer

23 therapy. The present review offers a summary of the biology of MET and its known functions in normal

24 physiology and carcinogenesis, followed by an overview of the most relevant MET-targeting strategies and

25 corresponding clinical trials, highlighting both past setbacks and promising future prospects. By placing

26 their efforts on a more precise stratification strategy through the genetic analysis of tumors, modern trials

27 such as the NCI-MATCH trial could revive the past enthusiasm for MET-targeted therapy. 


\section{Genesis of the MET field}

30 MET (also called c-Met or HGFR) is known as the receptor tyrosine kinase (RTK) for hepatocyte growth

31 factor (HGF) and its functions are essential for both embryogenesis and tissue regeneration [1]. However,

32 MET was originally discovered as a potent oncogene more than 30 years ago, and its role in cancer

33 development has been the object of numerous studies since the initial characterization [2].

34 In 1984, Cooper et al. reported the identification of a chemically-induced oncogene in a human 35 osteosarcoma cell line and suggested to name it MET, a reference to the mutagenic compound that was used 36 in their study: $N$-methyl- $N$ '-nitro- $N$-nitrosoguanidine [3]. While they initially mapped MET to chromosome

377 and excluded any relation to other oncogenes known at the time, two more years were needed to 38 demonstrate that the generated active oncoprotein actually was the result of the fusion of two separate loci

39 from distinct chromosomes. This genetic rearrangement consisted of a sequence derived from chromosome

401 on the 5 ' end (called tpr; translocated promoter region) and a section of the MET proto-oncogene from

41 chromosome 7 on the 3' end, leading to the strong expression of a chimeric mRNA due to the tpr-originating

42 sequence [4]. This resulted in the expression of a truncated cytoplasmic protein exhibiting constitutive

43 activation because of the spontaneous dimerization enabled by the leucine zipper domain of tpr [5]. Quickly

44 thereafter, MET was shown to have homology with both the growth factor receptor and the receptor tyrosine

45 kinase families [6], followed by the demonstration that it was indeed the receptor tyrosine kinase for HGF,

46 which was incidentally shown to be identical to another MET ligand called scatter factor (SF) [7].

47 These initial discoveries laid the groundwork for the investigation into the structure and biological functions 48 of MET, presented below.

\section{MET: gene, RNA and protein structure}

50 The locus encoding human MET is positioned on the long arm of chromosome 7 (7q31.2) and consists of 5124 exons transcribed into a 6637 nucleotide long mRNA, translated into a 1390 aminoacid long protein 
52 (canonical isoform, www.ncbi.nlm.nih.gov/gene/4233). MET transcription is controlled by a variety of

53 transcription factors: HIF-1 $\alpha$ under hypoxic conditions, AP-1 upon HGF stimulation, members of the PAX

54 family, NF-kB, Ets1, SP1, YB1 and the TCF family of transcription factors downstream of the Wnt pathway

55 [2]. Additional mechanisms of regulation, including epigenetic modifications such as DNA methylation,

56 histone acetylation and RNA interference have been studied and were summarized by Jack Zhang and Andy

57 Babic (2015) [8]. The major mRNA isoform resulting from splicing is translated into a single $170 \mathrm{kDa}$ chain

58 in the ER [9]. Subsequently, this precursor is glycosylated in the Golgi apparatus and cleaved by furin in

59 the post-Golgi compartment into $\alpha(50 \mathrm{kDa})$ and $\beta(145 \mathrm{kDa})$ chains, which remain linked by a disulfide

60 bond to form the mature form of MET. This mature MET will localize to the cell membrane with a single-

61 pass transmembrane $\beta$ subunit and the $\alpha$ subunit being entirely extracellular [8]. Several functional domains

62 span the length of the receptor: on the extracellular part, a SEMA domain encompasses the $\alpha$ and part of the

$63 \beta$ chains, followed by a PSI (plexin-semaphorin-integrin) domain and four IPT (immunoglobulin-plexin-

64 transcription factor) domains. The intracellular section of the receptor consists of a juxtamembrane (JM)

65 domain, a tyrosine kinase (TK) domain and a carboxyl-terminal multifunctional docking site (MFDS) [10].

66 On the extracellular side, the SEMA domain is essential for the dimerization and activation of MET [11] as

67 well as for binding of HGF [10], although the IPT domains have also been shown to have a high affinity for

68 HGF binding [12]. Between these two sections, the PSI domain contains several disulfide bonds necessary

69 for the proper orientation of the receptor towards the ligand [13]. Two regulatory phosphorylation sites

70 reside in the JM domain, directly below the cell membrane: serine 985 and tyrosine 1003 [14,15]. The

71 tyrosine kinase domain of MET is below the transmembrane domain and contains two tyrosine residues at

72 positions 1234 and 1235 . The phosphorylation of these sites is an essential step of the activation of the MET

73 receptor, leading to the phosphorylation of two additional tyrosines (1349 and 1356) in the carboxyl-

74 terminal docking site, enabling recruitment of adapter proteins and transduction of the signal [16]. See

75 Figure 1 for a schematic representation of MET. 
77 HGF was initially isolated from rat platelets in 1987 and cloned in 1989 [17] while SF was independently 78 described at the same time as a factor of cell motility [18]. The gene encoding HGF is located on 79 chromosome 7 (7q21.11) and contains 18 exons, transcribed into a 5987 nucleotide long mRNA, itself 80 translated into a 728 aminoacid long protein (www.ncbi.nlm.nih.gov/gene/3082). Transcriptional regulation

81 of this locus is controlled by, among other factors, TNF $\alpha$, IL-6, TGF $\beta$, CRE, and estrogens [19]. HGF is 82 secreted as a single chain that is proteolytically cleaved into $\alpha(69 \mathrm{kDa})$ and $\beta(34 \mathrm{kDa})$ subunits by various 83 proteases such as urokinase, matriptase and hepsin [20]. The two subunits remain linked by a disulfide bond 84 and bind heparin in the extracellular matrix via the $\alpha$ subunit $[17,21]$. The $\alpha$ chain contains an N-terminal

85 loop followed by four Kringle domains (K 1-4) while the $\beta$ subunit is homologous to serine proteases of the 86 chymotrypsin family but has no enzymatic activity (SPH domain) [22,23]. The $\alpha$ chain of HGF is sufficient

87 for binding with the IPT domains of MET with a high affinity, but the $\beta$ subunit is necessary for proper 88 MET activation by receptor homodimerization and binds the SEMA domain with lower affinity [12,21].

89 See Figure 1 for a schematic representation of HGF.

\section{MET in development and tissue regeneration}

\section{MET activation and signal transduction pathways}

92 As presented above, MET is a transmembrane protein activated by its homodimerization upon binding of

93 HGF. The signaling pathways activated by this event described below affect the cellular processes presented

94 in the next section.

95 Upon dimerization of MET, the tyrosine residues 1234 and 1235 in the kinase domain are 96 transphosphorylated, leading to phosphorylation of two additional tyrosine residues (1349 and 1356) in the 97 docking domain [16]. This phosphorylated docking domain forms an SH2 recognition motif enabling the 98 recruitment of adaptor and effector proteins such as Grb2, Gab1, SHC, CRK, PI3K, PLC $\gamma$, SHIP-2 and 99 STAT-3 $[2,16]$. One remarkable difference between MET and other RTKs is that Gab1 can bind MET either 
101 indirectly [24]. Acting together, these adapters either activate signaling cascades or recruit other proteins, 102 which will themselves signal downstream. This causes the activation of pathways essential for growth, 103 proliferation and cell motility through the following signaling cascades. Through binding and activation of 104 the PI3K subunit p85, MET induces Akt signaling, leading to the activation of mTOR, a complex 105 responsible for cellular growth and protein translation [16]. Additionally, Akt affects the p53 pathway by 106 activating MDM2 while inactivating pro-apoptotic factors such as BAD and thus offers protection from 107 apoptosis [25]. Finally, Akt activates positive cell cycle regulators such as Myc and cyclin D1 by inhibiting 108 GSK3 $\beta$ [26]. Another major signaling pathway downstream of MET is the MAPK cascade. By recruiting 109 SOS via Grb2, MET activates the small GTPase Ras, which subsequently activates Raf, a kinase responsible 110 for the phosphorylation of MEK1/2. Activated MEK1/2 will phosphorylate the next kinases in the cascade: 111 the Mitogen-Activated Protein Kinases (MAPK) ERK1/2. Active ERK1/2 translocate into the nucleus, 112 where their kinase activity promotes the stabilization of transcription factors responsible for motility and 113 cell cycle progression in the G1-S transition [27,28].

114 Additional pathways are activated by MET, such as the STAT-3 cascade and NF-kB signaling. STAT-3 115 binds and is phosphorylated by MET, leading to its translocation into the nucleus where it acts as a 116 transcription factor for several genes related to proliferation, differentiation and morphological changes such 117 as the formation of tubules [29]. NF- $\kappa \mathrm{B}$ is part of a family of rapid-acting transcription factors kept inactive 118 in the cytoplasm by IкB, which is itself controlled by IKK. Through the PI3K-Akt pathway, MET activates 119 IKK, which subsequently phosphorylates IкB, promoting its ubiquitination and degradation, releasing NF$120 \kappa \mathrm{B}$. Free NF- $\mathrm{BB}$ translocates into the nucleus and promotes the transcription of mitogenic, anti-apoptotic 121 and general cell-protective genes [30]. One more signaling axis worth mentioning, as it is connected to epithelial-mesenchymal transition (EMT) via the promotion of cell migration and anchorage-independent

123 growth, occurs through FAK via the activation of Src by MET. Activated FAK regulates cell-matrix 124 adhesion as well as cytoskeleton reorganization and promotes cell invasion [31]. This process is assisted by 125 the protective role of MET against anoikis, a form of cell death caused by cell detachment from the 
extracellular matrix [32]. Finally, MET can also crosstalk with various other membrane proteins, forming a

127 complex network. For instance, interaction with CD44v6, a glycoprotein involved in cell-matrix and cell-

128 cell adhesion, is required for HGF-dependent activation of MET in several cancer cell lines, is crucial for

129 Ras activation through SOS and connects MET to the cytoskeleton [33]; $\alpha 6 \beta 4$ integrin, a receptor for

130 laminin, plays a role in MET-controlled invasive growth by associating with MET and enhancing PI3K,

131 SHC and Ras signaling [34]; and the semaphorin receptor Plexin B1, a regulator of cell-cell interaction also

132 associates with MET to enhance its activation and thus promote invasive growth [35]. Moreover, MET has

133 been hypothesized to protect cells from apoptosis by interacting with Fas and preventing FasL binding [36].

134 Under normal circumstances, MET is downregulated by various mechanisms, including negative feedbacks.

135 Notably, active MET is phosphorylated on tyrosine 1003, leading to the recruitment of Cbl, an E3 ubiquitin

136 ligase that will target MET degradation via two pathways: multiple monoubiquitination promotes its

137 trafficking to the lysosome via the endosomal network for proteolytic degradation, whereas

138 polyubiquitination promotes its proteasomal degradation [15,37]. The activation of PKC through PLC $\gamma$

139 constitutes another negative feedback mechanism, as PKC-dependent phosphorylation of MET serine 985

140 downregulates MET tyrosine kinase activity, whereas PP2A can dephosphorylate serine 985 and counteract

141 the action of PKC [14]. Ubiquitin-dependent degradation of MET is not the only proteolytic mechanism

142 downregulating MET: ADAM metalloproteases can cleave MET in the extracellular domain and cause the

143 shedding of its ectodomain, followed by cleavage of the intracellular domain by $\gamma$-secretase [38]. This acts

144 in two ways to downregulate MET: first by reducing the number of receptors available for HGF binding,

145 second by releasing the ligand-binding domain of MET proteins, which will act as decoy receptors and thus

146 reduce the amount of free HGF available for MET activation. This mechanism acts independently of MET

147 activation and enables a constant low-grade attenuation of MET signaling [39]. Finally, several

148 phosphatases have been shown to inhibit MET directly by dephosphorylating its tyrosine residues. Such

149 phosphatases include PTP1B and TCPTP (which dephosphorylate tyrosines in the catalytic domain) as well

150 as DEP1, LAR and RPTP- $\beta$ (which target tyrosines in the docking domain) [40-43]. For an overview of the

151 pathways activated by MET and their biological outcomes, see Figure 1. Altogether, this depicts MET as a 
152 tightly regulated RTK involved in numerous cellular pathways. As MET has been shown to be crucial in 153 many processes in embryonic development and tissue repair, these pathways have been the object of 154 thorough studies, which are summarized in the next section.

\section{The physiological functions of MET}

156 As mentioned earlier, MET was initially discovered because of its oncogenic potential. However, the normal

157 function of MET is to act as essential regulator of various cellular function playing a pivotal role in the 158 development of various tissue types, as well as an important factor for tissue repair [1].

159 MET is mostly expressed by epithelial cells of various tissues and organs (including the gastrointestinal 160 tract, lung, liver, kidney, thyroid and skin) as well as some endothelial cells, cells in the hematopoietic 161 lineage, B cells and in neurons of various brains structures, while HGF is mainly expressed and secreted by 162 mesenchymal cells such as fibroblasts as a cytokine that modulates the proliferation of epithelial cells [44163 49]. As the other name of HGF - scatter factor - suggests, it also affects the "scattering" of MET-expressing 164 cells and controls invasive growth by its motogenic, mitogenic and morphogenic properties [50]. MET acts 165 as the main coordinator of the various stages of this complex program that involves proliferation, matrix 166 degradation, survival and migration: together MET and HGF form the basis for epithelial and mesenchymal 167 interaction, wound closure and angiogenesis at various stages of life [51]. As such, MET signaling is essential in vivo: deletion of HGF was shown to impair proper placental and fetal development in mice,

169 leading to in utero death. Among the affected tissues, liver was strongly impacted and showed drastic size 170 reduction [52]. By virtue of being expressed in many more organs, MET signaling is key for the 171 development of additional types of tissues, including the pancreas, muscles and various types of neurons 172 [53-55]. It regulates angiogenesis by promoting VEGF signaling while downregulating TSP-1, and thus 173 stimulating endothelial cell motility [45,56], and can also promote hematopoiesis [46]. As a token of the 174 pleiotropic functions of MET, a recently discovered mutation in the fourth IPT domain (F841V) has been 175 linked to hearing loss in humans [57]. 
176 MET functions are not limited solely to development: by promoting proliferation and invasion, it is a crucial

177 component of wound repair when the invasive growth of remaining cells needs to be reactivated to 178 reconstitute the damaged tissues. Along with other factors, MET signaling plays a key role in liver and 179 kidney regeneration [58,59]. Bone remodeling also involves MET signaling as both osteoclasts and 180 osteoblasts express MET and osteoclasts secrete HGF, leading to a crosstalk between these cell types to 181 ensure proper bone resorption and deposition [60]. Beyond its functions directly involved in repair, MET 182 signaling plays a protective role in damaged tissues (such as ischemic cardiac muscle) by protecting cells 183 from apoptosis [61]. As a whole, the HGF-MET tandem can be described as a crucial factor for cellular 184 proliferation, growth and motility. While these functions are essential for normal life, they can be hijacked 185 to support cancer development, which will be described in the next section.

\section{The oncogenic facet of MET: a key player in cancer development and}

\section{progression}

\section{Mechanisms of MET/HGF deregulation}

189 The initial discovery of MET was made by the generation of an artificially induced oncogenic fusion protein, and while this particular rearrangement was later also observed in human gastric cancerous lesions, a plethora of different mechanisms leading to MET deregulation can naturally occur at all stages of carcinogenesis and caught the interest of researchers promptly after the initial discovery of tpr-MET [62].

193 Various mechanisms have been shown to lead to MET deregulation in cancer, the most obvious one being

194 HGF-dependent: the stromal cells surrounding tumors frequently express HGF [63]. Ligand-dependent 195 activation of MET sometimes happens in an autocrine instead of paracrine fashion, however the 196 overexpression of MET is sometimes necessary for tumor cells to respond to HGF [64,65]. As a matter of 197 fact, MET overexpression is the most frequent cause of its constitutive activation in a ligand-independent 198 manner and results mostly from transcriptional upregulation. Examples of this have been reported in a 199 breadth of distinct carcinomas including thyroid, colorectal, ovarian, pancreatic, lung, and breast cancer 
200 [66-71]. Hypoxia is one of the mechanisms that can trigger increased transcription of MET: as mentioned 201 above, HIF-1 $\alpha$ can promote the transcription of MET [72]. Interestingly, MET overexpression can occur as 202 a response to radiotherapy through the ATM-NF-kB signaling pathway [73]. Activation of other oncogenes, 203 such as Ras, can upregulate MET expression as well [74]. A less common way for tumor cells to overexpress 204 MET is the amplification of its locus. Such gene amplification has been reported in esophageal 205 adenocarcinoma, medulloblastoma, cancer of the pancreas and of the gastrointestinal tract [75-78]. In lung 206 adenocarcinomas, MET amplification has also been documented as an acquired resistance mechanism to 207 EGFR targeted therapy [79]. Activation of MET due to its overexpression is thought to happen through its 208 spontaneous dimerization via the SEMA domain and is linked to cell-matrix adhesion mechanisms. [69,80].

209 However, some tumors rely on point mutations to activate MET without overexpressing it. The relevance 210 of activating MET mutations is underscored by the evidence that in HNSCC, the selection of somatic MET 211 mutations is promoted during metastatic spread [81]. These genetic aberrations include mutations in the 212 kinase domain of MET and have been described in both hereditary and sporadic forms of papillary renal 213 cell carcinomas as well as in gastric cancer $[82,83]$. Many of these mutations have been thoroughly studied 214 by their ectopic expression in various cellular systems, such as the NIH 3T3 mouse fibroblast model [84].

215 Ineffective downregulation of MET through the inactivation of pathways leading to MET dephosphorylation 216 or degradation can also lead to increased MET activation [85]. A relevant example of these mechanisms is 217 seen in a family of mutations leading to alternative splicing and hence skipping exon 14 of MET. The 218 resulting protein lacks a section of the juxtamembrane domain containing serine 985 and tyrosine 1003 219 which, as previously mentioned, are capital for the downregulation and degradation of MET [86]. These 220 mutations were first observed in lung cancer cases as a response mechanism to EGFR inhibition by MET 221 activation, and were later detected in subpopulations of brain and gastric cancer patients [87]. While a 222 relatively rare mutation, it could serve as a biomarker for patient stratification, as presented in later sections 223 of this review. 
224 Finally, MET activation can result from the activation of other RTKs. For instance, stimulation of EGFR 225 with its ligand EGF promotes MET activation via the MAPK signaling pathway when both RTKs are co226 expressed [88]. Another example is RON, an RTK structurally related to MET. These receptors can interact 227 together and are sufficiently similar for the activation of one to lead to the phosphorylation of the other [89]. 228 Similarly, several other RTKs, including IGF-1R and AXL, can interact with MET and cause its activation $229[90,91]$.

231 MET deregulation can happen at any stage of cancer development, and together all the activation 232 mechanisms presented above have been shown to promote both primary tumor formation and the transition 233 to metastatic disease [66]. Various studies have associated high MET expression and activation with poor 234 outcome [92]. For instance, high expression is known to correlate with markers of negative prognosis in 235 thyroid carcinoma, is a significant negative prognostic marker in NSCLC and is a predictor of tumor 236 invasion and lymph node metastases in colon cancer [93-95]. These last two examples are representative of 237 two classes of cancer that are of particular interest in the context of MET: gastrointestinal and lung cancers. 238 While MET mutations or amplifications are rare in gastric and colorectal cancer (CRC), overexpression of 239 MET and HGF at the mRNA and protein levels is common and can be observed in up to $40-70 \%$ of patient 240 samples, correlates with tumor stage and is a prognostic marker of clinical outcome [66,96-99]. Moreover, 241 MET expression is a predictor of invasive growth in gastric cancers and is associated with higher 242 occurrences of lymph node and liver metastases [32,95,100]. Cellular and in vivo models of gastric and 243 colorectal cancer have confirmed these observations and show that blockade of MET signaling reduces 244 tumor growth and spread [32,101-103]. Overall, while the various methods and scoring systems used to 245 assess MET-positivity make the prognostic value of its aberrant expression difficult to gauge, systematic 246 reviews and meta-analyses associate high MET expression with higher hazard ratios and poor prognosis in 247 gastric and colorectal cancer [104]. Interestingly, MET amplification has been observed as a resistance 248 mechanism to EGFR inhibition in metastatic colorectal cancer, a phenomenon that can also occur in 
249 NSCLC, either by selecting for pre-existing MET-amplified subclones or by inducing de novo copy number 250 gains $[105,106]$. Lung cancer studies also led to the discovery of another clinically relevant phenomenon: 251 MET exon 14 skipping mutations [107]. Because of such genetic aberrations, MET is considered a major 252 oncogene and a potential target in NSCLC [108]. Indeed, there is evidence for the efficacy of MET-targeting 253 therapies in NSCLC cases exhibiting MET alterations [86].

254 A more global picture of the role of MET in cancer depicts this RTK as an overall negative factor. Combined 255 data from multiple studies accessed from the cBioPortal website reveal that MET genetic alterations are 256 common in various types of cancers (Figure 2A), the highest mutation rate is observed in lung cancers 257 whereas esophageal squamous cell carcinomas show the highest amplification rate. RNA sequencing shows 258 overexpression in all cancer types: the highest median expression is found in papillary renal cell carcinoma 259 (PRCC), often combined with amplification or copy number gain, and the lowest overexpression is seen in 260 acute myeloid leukemia (AML) (Figure 2B). Strikingly, disease outcome is significantly worse for cases 261 with MET alterations compared with non-altered MET, showing a median overall survival of 66.7 versus 26292.4 months (Figure 2C).

263 As will be discussed further below, these observations have led to a great interest in the development of 264 MET targeting compounds, in particular for the treatment of MET-addicted tumors, as covered by various 265 reviews $[80,109]$.

267 Oncogene addiction, an expression that was first coined by Bernard Weinstein in 2002, denotes the fact that 268 despite having multiple genetic alterations, the survival and proliferation of some tumor cells rely 269 exclusively on one (or a few) specific oncogenes, the earliest examples being Myc, Ras, Bcr-Abl and 270 HER2/neu [110-114]. Thus, the inhibition of the addicting oncogene is often sufficient to induce 271 proliferative arrest, senescence, apoptosis or terminal differentiation in addicted cancer cells [115]. While 272 this phenomenon was first observed in artificial models, this field of research was quickly translated to 273 applicable treatment strategies in the clinic with oncogene-targeted therapies. Imatinib, a specific inhibitor 
274 of Bcr-Abl, the product of the Philadelphia chromosome translocation and a cause of chronic myeloid 275 leukemia, showed remarkable efficacy in patients [116]. Similarly, inhibition of HER2 with the monoclonal 276 antibody trastuzumab was shown to be efficacious and well tolerated in breast cancer patients displaying 277 strong overexpression of the receptor [117]. Over the years, evidence has emerged that oncogene addiction 278 can occur in many types of cancer and for several oncogenes, including major RTKs such as EGFR, VEGFR 279 and KIT [118]. Numerous clinical trials have shown the efficacy of targeted therapies against EGFR in lung 280 cancers driven by that oncogene, significantly improving progression free-survival (PFS) compared to 281 standard of care, but most trials failed to show higher overall survival [119-122]. Similarly, additional 282 examples of therapies targeting addiction to various oncogenes, both in preclinical and clinical trials, have 283 shown strong early response but failed to elicit durable effects [123]. This can be explained by the 284 development of resistance to the therapeutic compound via one or several mechanisms including the 285 selection or acquisition of protective mutations in the target and the escape from addiction, relying instead 286 on other pathways or oncogenes for cancer cell survival and proliferation, highlighting the need for 287 combination therapy $[118,124,125]$. As emphasized previously, MET is a potent oncogene involved in 288 various stages of neoplastic and metastatic development as well as in resistance mechanisms to therapies 289 targeting other oncogenes. Moreover, there is evidence for MET addiction in the preclinical and clinical 290 settings, making this receptor a prime target for targeted therapy [80]. For instance, the MET inhibitor PHA291665752 has proven remarkably efficient in inducing apoptosis in gastric cancer cell lines harboring 292 amplification of wild-type MET, while sparing cell lines without copy number alterations [103]. Similarly, 293 out of a panel of 35 human cancer cell lines, the eight lines with the highest expression of active MET were 294 shown to be significantly sensitive to the MET-targeting antibody ABT-700 [126]. While the most 295 promising results of MET-targeting therapies have been observed in the preclinical setting, their potential 296 translational application is supported by case reports describing encouraging results for their use in MET297 amplified lung and gastric cancer patients [127-129]. 
298 Targeting MET in the clinic: tools, trials, troubles and tentative

299 treatments

300 Many angles of attack have been used to target the HGF-MET signaling axis in cancer cells. A wide variety

301 of compounds have been developed, such as decoy ligands, docking site blockers and chimeric ribozyme

302 constructs leading to the degradation of MET mRNA [130-132]. However, such strategies have not been

303 clinically tested at this point. Therefore, the main focus of this section will be the two most commonly used

304 categories of compounds: antibodies targeting either HGF or MET, and small molecules inhibitors of MET.

305

306

307

308

309

310

311

312

313

314

315

316

317

318

319

320

\section{Antibodies targeting HGF and MET}

Targeting oncogenes with antibodies is sometimes viewed as preferable than the use of small molecule inhibitors because antibodies can be more specific, are usually well tolerated, can elicit cumulative cellular responses and have longer half-lives, but need to be administered intravenously whereas small molecule inhibitors are available orally and can target receptors regardless of their mechanism of activation (liganddependent or -independent) $[2,133]$. There currently is a number of humanized and fully human monoclonal antibodies (mAbs) targeting MET or HGF in development or in clinical trials. The main mechanism of action of anti-HGF mAbs is to prevent the binding of HGF to MET by targeting domains required for their interaction. Antibodies targeting MET can act similarly to prevent HGF binding, but have also shown indirect mechanisms of actions such as receptor degradation or downregulation and immune-mediated antibody-dependent cellular cytotoxicity (ADCC) or complement-dependent cytotoxicity (CDC) [133].

HGF-targeting mAbs include the fully human IgG2 rilotumumab (AMG 102, Amgen, Thousand Oaks, California, USA) preventing interaction with MET by targeting the SPH domain of HGF [134], the humanized IgG1 ficlatuzumab (AV-299, Aveo Pharmaceuticals, Cambridge, Massachusetts, USA) [135], and the mAb L2G7 (Galaxy Biotech, Sunnyvale, California, USA)/TAK-701 (Takeda pharmaceutical, Osaka, Japan) [136], all of which are under clinical investigation. Additional anti-HGF antibodies are also 
being studied at the preclinical level, such as SFN68, which binds HGF in complex with MET, and the

322 bispecific (MET- and serum albumin-binding) nanobodies 1E2-Alb1 and 6E10-Alb8 [137,138].

323 As mentioned before, MET targeting antibodies can elicit diverse cellular responses depending on their 324 nature and the domain they bind. R13 and R28 (OncoMed Pharmaceuticals, Redwood city, California, USA) 325 are fully human mAbs used in tandem that compete with HGF for binding and induce ADCC [139]. 326 SAIT301 (Samsung Inc, Yongin, Republic of Korea) is a humanized mAb that leads to MET downregulation 327 by internalization and lysosomal degradation via LRIG1 [140]. Similarly, emibetuzumab (LY2875358, Eli 328 Lilly, Indianapolis, Indiana, USA) is a humanized IgG4 that induces internalization and degradation of MET 329 and prevents HGF binding [141]. ABT-700 (AbbVie, Lake Bluff, Illinois, USA) is a humanized IgG1 that 330 blocks HGF binding and induces ADCC by recruiting natural killer cells to mediate the lysis of the targeted 331 cells [126]. An antibody-drug conjugate (ADC) has been developed from ABT-700: ABBV-399 (AbbVie). 332 This ADC is composed of the antibody and the cytotoxic microtubule inhibitor monomethylaurstatin E, 333 connected by a cleavable linker. Using an ADC could present the advantage of efficiently targeting cancer 334 cells with high expression of MET regardless of MET activation or addiction, while sparing normal cells 335 expressing lower levels of MET [142]. Onartuzumab (MetMab/OA-5D5, Genentech, South San Francisco, 336 California, USA) is a humanized monovalent antibody that competes with HGF by binding to the SEMA 337 domain of MET [143]. DN30 (Metheresis Translational Research SA, Lugano, Switzerland) is a chimeric 338 mouse IgG2A that induces ADAM-10 mediated shedding of receptor by binding the $4^{\text {th }}$ IPT domain of MET 339 and altering the conformation of the receptor, which has the benefit of preventing MET activation and 340 releasing decoy MET moieties that can titer HGF away from cancer cells. The original form of the 341 compound had a flaw common to several receptor-targeting antibodies: since antibodies contain two binding 342 domains, DN30 could act as a partial agonist of MET by bringing two receptors together, leading to ligand343 independent dimerization and activation. This issue was solved by converting the compound to a smaller 344 monovalent Fab (MvDN30), which unfortunately had an increased renal clearance due to its small size 345 [144]. Two strategies could be explored to solve the resulting shorter half-life: stabilizing the plasma 346 availability of the compound (for example by PEGylation) or enabling continuous production of the Fab in 
347 patients by gene transfer therapy, a route that is investigated in preclinical models of glioblastoma

348 multiforme, where MET has been described as a marker of cancer stem cells [145].

\section{Small molecule inhibitors of MET}

350 As mentioned earlier, small molecule tyrosine kinase inhibitors (TKIs) have the benefit of targeting the 351 activated receptor regardless of ligand presence by preventing ATP from reaching the ATP-binding pocket 352 of the kinase domain [146]. However, TKIs can vary in their specificity: some compounds have 353 demonstrated remarkable specificity for MET while others inhibit several kinases with varying affinities.

354 One notable exception to the ATP-competitive mode of action is the case of Tivantinib (ARQ197, Daiichi

355 Sankyo, Tokyo, Japan, and ArQule Inc, Woburn, Massachusetts, USA), which was initially presented as an 356 allosteric inhibitor of MET locking the receptor in the inactive conformation, but has subsequently been 357 shown to exert its cytotoxic activity by interfering with microtubule dynamics without affecting MET 358 activation [147]. Table 1 lists relevant examples of non-selective and selective TKIs that are at various 359 stages of clinical trials $[2,109]$.

\section{MET/HGF targeting in clinical trials}

361 Over the years, many of the compounds presented above have progressed through clinical trials with varying 362 degrees of success. While there are too many completed and ongoing trials to be comprehensively presented 363 here, previous reviews have regularly summarized their progress, and only the most relevant examples of 364 completed or ongoing studies are highlighted below [2,80,109,133,146,148]. It should be noted that currently only two non-selective MET TKIs have been approved for use, but not specifically for their METinhibiting action: cabozantinib for medullary thyroid cancer and kidney cancer, and crizotinib for ALK and ROS1 positive NSCLC $[149,150]$. However, these and other compounds are still being evaluated for other cases, with many trials focusing on lung and gastrointestinal cancers due to the role this signaling axis plays

369 in the development and progression of these malignancies, as mentioned earlier. Nonetheless, a number of 370 studies is also being performed for other types of cancer, such as HCC, castration-resistant prostate cancer, renal cell carcinoma or metastatic melanoma [151]. Altogether, these trials have produced mixed results for 
372 the use of MET/HGF-targeting compounds in the clinic. As mentioned earlier, the main mechanism of MET 373 activation is ligand-independent and relies on the overexpression of the receptor, explaining why the 374 majority of the currently explored strategies focus on targeting MET rather than HGF. However, HGF375 targeting compounds have also been investigated and notable examples are presented below.

The anti-HGF mAb rilotumumab has undergone phase III clinical trials (RILOMET-1 and 2, NCT01697072 and NCT02137343) as first-line therapy in patients with advanced MET-positive gastric and gastroesophageal cancer, in combination with ECX chemotherapy. Unfortunately, after the promising results of a phase II trial, the RILOMET studies showed that the addition of rilotumumab to chemotherapy performed worse than chemotherapy alone, leading to the early termination of the trials $[152,153]$. Similarly, the phase II MEGA study compared the combination of rilotumumab plus mFOLFOX6 versus mFOLFOX6 alone as a first-line treatment for HER2-negative advanced gastric and gastroesophageal cancer but failed to show improvements with the addition of rilotumumab (NCT01443065).

The phase III METGastric study evaluated the benefits of the addition of onartuzumab to mFOLFOX6 as a first-line treatment of MET-positive but HER2-negative metastatic gastric and gastroesophageal adenocarcinoma, but failed to show any significant improvement [154]. A promising phase II clinical trial studying the addition of onartuzumab to EGFR inhibition for the treatment of advanced NSCLC showed benefit in the MET-positive population, but failed to confirm this result in a subsequent phase III trial. Two hypotheses have been proposed to explain this unfortunate turn of events: compounds preventing the interaction between MET and HGF might be ineffective in this setting (for example in the case of ligandindependent activation of MET), or the biomarkers used for patient recruitment were inadequate $[155,156]$.

392 The results of additional phase III studies are still pending.

393 Crizotinib, as mentioned before, is a multitarget inhibitor and has been approved for the treatment of NSCLC 394 expressing the fusion proteins EML4-ALK or CD74-ROS1, two types of cancer where its efficacy was 395 demonstrated $[149,150]$. However, its pertinence as a MET inhibitor is still being evaluated. Early results of a Crizotinib trial showed some promise for the treatment of NSCLC harboring MET exon 14 skipping 
mutations [157]. The phase I PROFILE 1001 trial has also been testing the efficacy of this compound in 398 lung cancer and other solid tumors exhibiting MET, ALK or ROS1 alteration. While the study is still 399 ongoing, preliminary results have shown benefits for patients with advanced, ROS1-rearranged or MET400 amplified NSCLC [158,159]. Likewise, several ongoing phase II trials are evaluating the performance of 401 crizotinib in NSCLC and other cancers, focusing on genetic alterations such as MET amplification and 402 mutation (NCT02034981, NCT02499614, NCT03088930). Similar trials are also being performed for 403 gastric cancer: a pilot phase I study showed that MET-amplified gastroesophageal adenocarcinoma could 404 transiently respond to crizotinib [160], the subsequent phase II study has yet to publish conclusions 405 (NCT02435108). At the present time, the phase I MErCuRIC1 trial represents a first attempt at combining 406 crizotinib with a MEK inhibitor in a cohort of CRC patients harboring amplified MET and either wild-type 407 or mutated Ras (NCT02510001) [161].

408 Cabozantinib is the second non-selective MET inhibitor that has been approved for use in the clinic: for 409 advanced, unresectable medullary thyroid cancer and for kidney cancer as a second-line treatment after anti410 angiogenic therapy [162,163]. As for crizotinib, the approved use of cabozantinib does not involve the status 411 of MET in the tumor. There is currently limited evidence for the benefit of using cabozantinib specifically 412 to target MET: a case report presented one patient with MET exon 14 skipping who showed complete 413 response, and the phase III CELESTIAL trial in HCC, a disease where MET has been implicated, showed 414 a slight but significant improvement in PFS and overall survival for patients treated with cabozantinib, but 415 did not report on a MET-specific response [157,164-166]. Several phase II trials are currently testing 416 cabozantinib specifically for lung and salivary gland cancer harboring MET alterations (NCT03729297, 417 NCT01639508, NCT03911193, NCT02132598).

418 Selective MET inhibitors are also being investigated in clinical trials, with some studies specifically 419 focusing on the status of MET in the tumors. Capmatinib displayed improvements for patients with MET420 overexpressing or amplified NSCLC in a phase I trial, and a phase Ib/II study with EGFR-targeted therapy421 resistant NSCLC showed benefits for tumors having high MET copy number gains [167,168]. Numerous 
422 phase II trials are currently testing Capmatinib in MET-dysregulated NSCLC and HCC (NCT03693339, 423 NCT02750215, NCT01737827, NCT01610336, NCT02414139, NCT02276027).

424 Tepotinib had an antitumor effect in a phase I study, which led to the start of a phase I/II study in MET425 positive HCC as an alternative to sorafenib (an inhibitor of VEGFR) [169-172] and the opening of the 426 recruitment for a phase II trial in advanced NSCLC harboring MET exon 14 skipping mutations or MET 427 amplification (NCT02864992). Recently, a trial has been set up to assess the combination of tepotinib with 428 a $3^{\text {rd }}$ generation EGFR inhibitor to treat EGFR-mutated, MET-amplified NSCLC having acquired resistance 429 to EGFR inhibitors (NCT03940703).

430 AMG 337 has been evaluated in a phase I trial for various advanced malignancies where it elicited a 431 favorable response in MET-amplified tumors [173]. Unfortunately, the following phase II study was 432 terminated early after an intermediate review revealed that the treatment had a lower-than-expected activity 433 compared to the phase I trial, despite the selection of patients exhibiting MET amplification [173]. Another 434 phase II study is currently recruiting patients with advanced or metastatic solid tumors harboring MET 435 overexpression or exon 14 skipping mutations (NCT03147976).

436 Savolitinib is involved in numerous trials at different stages, including a phase II study in lung cancer, 437 selecting for MET exon 14 mutated cases (NCT02897479), and several phase I/II studies in advanced gastric 438 adenocarcinoma or metastatic CRC with MET overexpression as second- or third-line treatment, alone or 439 combined with docetaxel (NCT03592641, NCT02449551, NCT02447380). Of note, savolitinib is also 440 being evaluated in a phase III study in MET-driven, unresectable, locally advanced or metastatic PRCC 441 (NCT03091192), following a promising phase II trial in a similar setting where HGF mutations or MET 442 alterations correlated with better response (NCT02127710) [174]. 


\section{The road ahead: better aiming, or better weapons?}

\section{The stratification struggles}

445 Patient stratification for targeted therapy is not always a trivial affair: some targets can be more difficult to

446 select than others. Whereas HER2 amplification is a common phenomenon in breast and gastric cancer (15$44730 \%$ and $21-33 \%$, respectively) [175], leading to a large population in which treatment options such as

448 trastuzumab and lapatinib have been tested and validated, true MET amplification is a rarer occurrence.

449 Similarly, activating mutations are less frequently observed in MET than in EGFR, which can be mutated 450 in up to $15 \%$ of Caucasian NSCLC patients [176]. Unlike these two examples, MET alterations have been 451 detected in less than $10 \%$ of the cases for most cancer types (see Figure 2A), and this comparatively low 452 MET alteration frequency makes it a challenging candidate for stratification. Furthermore, not all MET 453 alterations might lead to sensitization to targeted therapy. A recurring question in the field of targeted 454 therapy is the validity of the target: specific kinase inhibitors can only work if the corresponding kinase is 455 essential to the growth and survival of the cancer cells $[110,118]$. Such oncogene addiction can be difficult 456 to establish outside of a preclinical cellular model, and the setbacks from early clinical trials targeting MET 457 could have resulted from inappropriate patient selection. Indeed, patient stratification was often initially 458 made based on MET expression in the tumor, regardless of MET activation (denoted by the phosphorylation 459 of MET tyrosines 1234/1235), potentially rendering MET targeting ineffective [177]. Indeed, only a fraction 460 of MET positive tumors are actually p-MET positive [178]. One would think that assessing MET 461 phosphorylation instead of MET expression in the tumor would be a simple solution to that problem. 462 Unfortunately, the detection of phosphorylated MET by immunohistochemistry (IHC) remains complicated: 463 unless extreme precautions are taken in the processing of the tissue and the detection process, the 464 phosphorylation can be lost [179]. Research from Huang and colleagues highlights the complexity of 465 defining the proper way to measure MET expression and activation by IHC on archival tissue, their work 466 suggests that every type of cancer might need a specific companion diagnostic, potentially each with a 467 different antibody [180]. 
Early trials have been criticized for casting too wide a net by selecting patients using MET detection by IHC

469 [181]. Therefore, the focus shifted to the detection of genetic alterations showing a better correlation with 470 the response to MET-targeted therapies, such as MET amplification or MET exon 14 skipping mutations.

471 However, MET amplification assessment by fluorescence in situ hybridization (FISH) is controversial as

472 well. Some trials deem that duplication of the whole chromosome 7 is not enough to depict true MET 473 amplification, and consider that only the amplification of the MET locus, defined by a high ratio of MET to 474 centromere 7 (MET/CEP7), represents an oncogenic event [181]. What MET/CEP7 threshold should be 475 applied remains controversial: some trials selected patients with a ratio higher than 2 , whereas others defined 476 MET amplification as a MET/CEP7 higher than five, the most stringent threshold suggesting that less than $4771 \%$ of the patients might exhibit true amplification, whereas less stringent settings include up to $7 \%$ in the 478 MET-amplified group in gastric or lung cancer studies [181,182]. The stratification of patients harboring 479 MET exon 14 skipping mutations, which is already being applied in some trials as presented above, could 480 be a viable alternative selection strategy, enabled by the non-intrusive detection in circulating tumor DNA 481 [157,179]. Nevertheless, it is important to remember that MET exon 14 skipping only occurs in up to 4\% 482 of NSCLC cases, and selecting such a small subset of patients could exclude other potential responders 483 [183]. Regardless of the stratification method, it has become clear that only a minute fraction of tumors 484 exhibit MET addiction, and thus the potential response to standard anti MET treatments might only prove 485 effective for a very limited population $[157,181]$. However, recent advances in the field of immunotherapy 486 could extend MET targeting therapies to tumors expressing MET without addiction to the oncogene, as 487 presented in the next section.

\section{The rise of personalized immunotherapy}

489 The generation and injection of chimeric antigen receptor (CAR) T-cells is a type of adoptive 490 immunotherapy and a promising method currently being developed for the treatment of cancer. The 491 principle behind CAR T therapy is the genetic engineering of a patient's T-cells ex vivo to express an 492 artificial receptor (CAR) targeting a surface protein specifically expressed by the targeted tumor cells. 
493 Modified T-cells are then infused into the patient, where they can target tumor cells independent of the 494 major histocompatibility complex and trigger tumor cell death primary by cytolysis and by extrinsic 495 apoptosis induction [184]. Thus, as opposed to TKIs and mAbs which can only affect MET-addicted cells 496 or cells that express high levels of MET, this therapeutic approach can potentially be used to target cells 497 expressing the target at a level too low for standard targeted therapy, or those that are not addicted to the 498 target $[185,186]$. Currently, CAR T-based therapies have shown the most promise for hematologic 499 malignancies, while their application to solid tumors remains a challenge [187]. Nevertheless, efforts are 500 being made to target proteins such as EGFR [188], EphA2 [189] and HER2 [190]. Similarly, MET has been 501 the object of recent studies evaluating its potential as a CAR T target. In order to overcome the challenge of 502 solid tumor invasion by T-cells, Tchou and colleagues assessed the feasibility of intratumoral injection of 503 MET-targeting CAR T-cells for the treatment of metastatic breast cancer. Intratumoral injection has the 504 added benefit of reducing on-target off-tumor effect, which was further lessened by the transient expression 505 of the CAR. After observing tumor control with this approach in a mouse xenograft model, six patients were 506 enrolled for a phase 0 trial. All patients treated presented MET-positive tumors and the injection of CAR T507 cells was well tolerated. While no clinical response could be measured, systemic dissemination of CAR Tcells remained limited and histological analysis of the sites of injection revealed the induction of necrosis, immune cell infiltration and loss of MET-positive cells. This trial was limited in its scope, but serves as an encouraging proof of concept, opening the door to further studies with larger cohorts and proper controls to

511 evaluate the efficacy of MET-targeting CAR T therapies [191]. While the study by Tchou et al. generated 512 a CAR with the single chain variable fragment of an antibody (onartuzumab), other approaches have also 513 been described. Thayaparan and colleagues generated a CAR by using the NK1 domains of HGF, hijacking 514 a natural MET-binding mechanism. They applied this approach to the treatment of mesothelioma and 515 showed positive results in vitro with MET-expressing cell lines. They also showed the safety and efficacy 516 of locally injected MET-targeting CAR T-cells in an intraperitoneal mouse xenograft model, leading to 517 tumor regression, albeit only when injecting high doses of CAR T-cells [192]. These promising early results 518 warrant further research into the efficacy of such therapies in the clinical setting, however the monitoring 
519 and management of toxicity remains a crucial parameter to promote the application of CAR $\mathrm{T}$ therapies $520 \quad[187]$.

521 Conclusion: the past, present and future of MET signaling-targeted

\section{2 therapies}

523 As presented in this review, the results of MET/HGF-targeting agents in clinical trials are underwhelming.

524 However, lessons can be learned from both successes and failures, which should help design future trials 525 with improved patient selection and drug combinations. It could be remarked that antibody-based therapies 526 seem to fare worse than small molecule inhibitors. However this might stem from an inferior patient 527 selection process, as it was often made on the basis of MET expression measured by IHC, a technique that 528 has limitations due to variables such as fixation and processing of the tissue or subjectivity in the scoring 529 [193]. Furthermore, measuring MET expression has the downside of not necessarily correlating with MET 530 activation, denoted by phosphorylation of tyrosine residues. Despite evidence that the presence of 531 phosphorylated MET is associated with tumor progression and is a predictor of metastasis and survival in 532 some types of tumors, assessing MET activation or addiction in this fashion has not been widely adopted 533 for patient accrual [194,195]. As is seen for EGFR-targeting therapies, where efforts are made to enrich for 534 patients with activating EGFR mutations, screening patients for genetic alterations that are associated with 535 MET activation (notably MET exon 14 skipping mutation and MET amplification), rather than simply 536 measuring MET expression, is now considered a superior selection strategy and predictor of response to 537 MET inhibition in the case of NSCLC [86,157,196,197]. Indeed, ambitious efforts are currently being made 538 to improve personalized therapy: the MATCH phase II clinical trial is aiming at stratifying patients by 539 genetic alteration instead of histology to provide them with the appropriate treatment, such as crizotinib in 540 the presence of MET overexpression or exon 14 mutations [198,199].

541 Another lesson can be learned from EGFR-targeting therapies: the inevitable rise of resistance, for example 542 as a result of the acquisition of a mutation (e.g. EGFR T790M) that can null the effect of the TKI or by 
543 relying on another RTK such as MET [200]. In the case of EGFR, this has been addressed in two ways:

544 either by using more recent inhibitors that can overcome the protective effect of the mutation, such as 545 osimertinib, or by combining EGFR and MET inhibition [197,201]. Similar approaches could be effective 546 to face the expected emergence of resistance to MET-targeting compounds. Several such resistance 547 mechanisms in MET-driven tumors and cell lines have been documented and include the selection of 548 preexisting subclones harboring MET Y1248H (or Y1248C) mutations, rendering cells resistant to 549 crizotinib, or MET D1228V, protecting against savolitinib. While these mutated variants of MET can be 550 inhibited by glesatinib or cabozantinib, respectively, additional mutations could be selected or acquired in 551 treated cells and render them resistant to virtually any inhibitor [202-204]. Resistance to MET inhibition 552 can also occur through the amplification of HER2 or FGFR2 and de novo Ras mutations, which would 553 require the combined use of several targeted therapies preemptively or after relapse $[205,206]$. Drug 554 combinations can also be rationally designed to directly target processes that involve several RTKs. One 555 such example would be the combination of VEGFR and MET inhibitors, as both are involved in 556 angiogenesis [130,207]. Interestingly, such a combination could be necessary to overcome the unforeseen 557 activation of MET by the inhibition of VEGFR in a particular setting. Indeed, targeting VEGFR in 558 glioblastoma multiforme can have the unexpected effect of enhancing MET activation, leading to a more 559 invasive tumor phenotype [208].

560 Altogether, despite middling success, preclinical and clinical studies show potential for MET as a 561 therapeutic target, provided improvements in patient stratifications are made. The recent development of 562 MET targeting immunotherapy and the granting by the FDA of a priority status to both capmatinib and 563 tepotinib, based on the promising results of the GEOMETRY mono-1 (NCT02414139) and the VISION 564 (NCT02864992) studies, highlight that MET remains an appealing target and could renew interest in this oncogene. Since the resistance to the inhibition of various oncogenes (such as EGFR, BRAF, MEK or FGFR) can arise through the activation of MET [109], looking forward, one can expect the development of combination therapies that could pre-emptively address resistance and have a synergistic effect with METtargeting therapies. 


\section{References}

5711 Petrini I. Biology of MET : a double life between normal tissue repair and tumor progression 2015;3.

5722 Comoglio PM, Trusolino L, Boccaccio C. Known and novel roles of the MET oncogene in cancer: a $573 \quad$ coherent approach to targeted therapy. Nat Rev Cancer. 2018.

5743 Cooper CS, Park M, Blair DG, Tainsky MA, Huebner K, Croce CM, et al. Molecular cloning of a new transforming gene from a chemically transformed human cell line. Nature. 1984;311:29-33.

5764 Park M, Dean M, Cooper CS, Schmidt M, O'Brien SJ, Blair DG, et al. Mechanism of met oncogene activation. Cell. 1986;45:895-904.

Rodrigues GA, Park M. Dimerization mediated through a leucine zipper activates the oncogenic potential of the met receptor tyrosine kinase. Mol Cell Biol. 1993;13:6711-6722.

Dean M, Park M, Le Beau MM, Robins TS, Diaz MO, Rowley JD, et al. The human met oncogene is related to the tyrosine kinase oncogenes. Nature. 1985;318:385-388.

Naldini L, Weidner KM, Vigna E, Gaudino G, Bardelli A, Ponzetto C, et al. Scatter factor and hepatocyte growth factor are indistinguishable ligands for the MET receptor. EMBO J. 1991;10:2867-2878.

Zhang J, Babic A. Regulation of the MET oncogene: Molecular mechanisms. Carcinogenesis. 2015;37:345-355.

Giordano S, Di Renzo MF, Narsimhan RP, Cooper CS, Rosa C, Comoglio PM. Biosynthesis of the protein encoded by the c-met proto-oncogene. Oncogene. 1989;4:1383-1388.

Gherardi E, Youles ME, Miguel RN, Blundell TL, lamele L, Gough J, et al. Functional map and domain structure of MET, the product of the c-met protooncogene and receptor for hepatocyte growth factor/scatter factor. Proc Natl Acad Sci. 2003;100:12039-12044.

Kong-Beltran M, Stamos J, Wickramasinghe D. The Sema domain of Met is necessary for receptor dimerization and activation. Cancer Cell. 2004;6:75-84.

Basilico C, Arnesano A, Galluzzo M, Comoglio PM, Michieli P. A high affinity hepatocyte growth factor-binding site in the immunoglobulin-like region of met. J Biol Chem. 2008;283:21267-21277.

Kozlov G, Perreault A, Schrag JD, Park M, Cygler M, Gehring K, et al. Insights into function of PSI domains from structure of the Met receptor PSI domain. Biochem Biophys Res Commun. 2004.

4 Hashigasako A, Machide M, Nakamura T, Matsumoto K, Nakamura T. Bi-directional regulation of Ser-985 phosphorylation of c-Met via protein kinase $C$ and protein phosphatase $2 A$ involves c-Met activation and cellular responsiveness to hepatocyte growth factor. J Biol Chem. 2004;279:2644526452.

Peschard P, Ishiyama N, Lin T, Lipkowitz S, Park M. A conserved DpYR motif in the juxtamembrane domain of the Met receptor family forms an atypical c-Cbl/Cbl-b tyrosine kinase binding domain 
Ponzetto C, Bardelli A, Zhen Z, Maina F, Zonca PD, Giordano S, et al. A multifunctional docking site mediates signaling and transformation by the hepatocyte growth factor/scatter factor receptor family. Cell. 1994;77:261-271.

17 Nakamura T, Nishizawa T, Hagiya M, Seki T, Shimonishi M, Sugimura A, et al. Molecular cloning and expression of human hepatocyte growth factor. Nature. 1989;342:440-443.

Gherardi E, Gray J, Stoker M, Perryman M, Furlong R. Purification of scatter factor, a fibroblastderived basic protein that modulates epithelial interactions and movement. Proc Natl Acad Sci. 1989;86:5844-5848.

Zarnegar R. Regulation of HGF and HGFR gene expression. In: Goldberg ID, Rosen EM, eds. Ep. Interact. Cancer, vol. 74, . BirkhauserBirkhäuser, 1995:33-49.

Herter S, Piper DE, Aaron W, Gabriele T, Cutler G, Cao P, et al. Hepatocyte growth factor is a preferred in vitro substrate for human hepsin, a membrane-anchored serine protease implicated in prostate and ovarian cancers. Biochem J. 2005;390:125-136.

Stamos J, Lazarus RA, Yao X, Kirchhofer D, Wiesmann C. Crystal structure of the HGF $\beta$-chain in complex with the Sema domain of the Met receptor. EMBO J. 2004;23:2325-2335.

Matsumoto K, Nakamura T. Hepatocyte growth factor: Molecular structure and implications for a central role in liver regeneration. J Gastroenterol Hepatol. 1991;6:509-519.

23 Lokker NA, Mark MR, Luis EA, Bennett GL, Robbins KA, Baker JB, et al. Structure-function analysis of hepatocyte growth factor: identification of variants that lack mitogenic activity yet retain high affinity receptor binding. EMBO J. 1992;11:2503-2510.

Wang W, Xu S, Yin M, Jin ZG. Essential roles of Gab1 tyrosine phosphorylation in growth factormediated signaling and angiogenesis. Int J Cardiol. 2015;181:180-184.

25 Xiao GH, Jeffers M, Bellacosa A, Mitsuuchi Y, Vande Woude GF, Testa JR. Anti-apoptotic signaling by hepatocyte growth factor/Met via the phosphatidylinositol 3-kinase/Akt and mitogen-activated protein kinase pathways. Proc Natl Acad Sci U S A. 2001;98:247-252.

Trusolino L, Bertotti A, Comoglio PM. MET signalling: Principles and functions in development, organ regeneration and cancer. Nat Rev Mol Cell Biol. 2010;11:834-848.

Fixman ED, Fournier TM, Kamikura DM, Naujokas MA, Park M. Pathways downstream of Shc and Grb2 are required for cell transformation by the Tpr-Met oncoprotein. J Biol Chem. 1996;271:13116-13122.

Johnson GL, Lapadat R. Mitogen-activated protein kinase pathways mediated by ERK, JNK, and p38 protein kinases. Science. 2002;298:1911-1912.

Zhang YW, Wang LM, Jove R, Vande Woude GF. Requirement of Stat3 signaling for HGF/SF-Met mediated tumorigenesis. Oncogene. 2002;21:217-226.

30 Fan S, Gao M, Meng Q, Laterra JJ, Symons MH, Coniglio S, et al. Role of NF-kB signaling in hepatocyte growth factor/scatter factor-mediated cell protection. Oncogene. 2005;24:1749-1766. 
Hui AY, Meens JA, Schick C, Organ SL, Qiao H, Tremblay EA, et al. Src and FAK mediate cell-matrix adhesion-dependent activation of met during transformation of breast epithelial cells. J Cell Biochem. 2009;107:1168-1181.

32 Toiyama Y, Yasuda H, Saigusa S, Matushita K, Fujikawa H, Tanaka K, et al. Co-expression of hepatocyte growth factor and c-Met predicts peritoneal dissemination established by autocrine hepatocyte growth factor/c-Met signaling in gastric cancer. Int J Cancer. 2012;130:2912-2921.

33 Orian-Rousseau V, Morrison H, Matzke A, Kastilan T, Pace G, Herrlich P, et al. Hepatocyte growth factor-induced Ras activation requires ERM proteins linked to both CD44v6 and F-actin. Mol Biol Cell. 2007;18:76-83.

34 Trusolino L, Bertotti A, Comoglio PM. A signaling adapter function for $\alpha 6 \beta 4$ integrin in the control of HGF-dependent invasive growth. Cell. 2001;107:643-654.

35 Giordano S, Corso S, Conrotto P, Artigiani S, Gilestro G, Barberis D, et al. The semaphorin 4D receptor controls invasive growth by coupling with Met. Nat Cell Biol. 2002;4:720-724.

36 Wang X, DeFrances MC, Dai Y, Pediaditakis P, Johnson C, Bell A, et al. A mechanism of cell survival: Sequestration of Fas by the HGF receptor Met. Mol Cell. 2002;9:411-421.

37 Carter S, Urbé S, Clague MJ. The met receptor degradation pathway: Requirement for Lys 48-linked polyubiquitin independent of proteasome activity. J Biol Chem. 2004;279:52835-52839.

38 Foveau B, Ancot F, Leroy C, Petrelli A, Reiss K, Vingtdeux V, et al. Down-regulation of the met receptor tyrosine kinase by presenilin-dependent regulated intramembrane proteolysis. Mol Biol Cell. 2009;20:2495-2507.

39 Schelter F, Kobuch J, Moss ML, David Becherer J, Comoglio PM, Boccaccio C, et al. A disintegrin and metalloproteinase-10 (ADAM-10) mediates DN30 antibody-induced shedding of the met surface receptor. J Biol Chem. 2010;285:26335-26340.

40 Xu Y, Xia W, Baker D, Zhou J, Cha HC, Voorhees JJ, et al. Receptor-type Protein Tyrosine Phosphatase $\beta$ (RPTP- $\beta$ ) directly dephosphorylates and regulates Hepatocyte Growth Factor Receptor (HGFR/Met) function. J Biol Chem. 2011;286:15980-15988.

41 Mitchell CJ, Kim MS, Zhong J, Nirujogi RS, Bose AK, Pandey A. Unbiased identification of substrates of protein tyrosine phosphatase ptp-3 in C. elegans. Mol Oncol. 2016;10:910-920.

42 Sangwan V, Paliouras GN, Abella J V, Dubé N, Monast A, Tremblay ML, et al. Regulation of the Met receptor-tyrosine kinase by the protein-tyrosine phosphatase $1 \mathrm{~B}$ and T-cell phosphatase. J Biol Chem. 2008;283:34374-34383.

43 Palka HL, Park M, Tonks NK. Hepatocyte growth factor receptor tyrosine kinase Met is a substrate of the receptor protein-tyrosine phosphatase DEP-1. J Biol Chem. 2003;278:5728-5735.

44 Prat M, Narsimhan RP, Crepaldi T, Rita Nicotra M, Natali PG, Comoglio PM. The receptor encoded by the human C-MET oncogene is expressed in hepatocytes, epithelial cells and solid tumors. Int J Cancer. 1991;49:323-328.

45 Bussolino F, Di Renzo MF, Ziche M, Bocchietto E, Olivero M, Naldini L, et al. Hepatocyte growth factor is a potent angiogenic factor which stimulates endothelial cell motility and growth. J Cell Biol. 
46 Nishino T, Hisha H, Nishino N, Adachi M, Ikehara S. Hepatocyte growth factor as a hematopoietic regulator. Blood. 1995;85:3093-3100.

47 Taher TEI, Tjin EPM, Beuling EA, Borst J, Spaargaren M, Pals ST. c-Cbl Is Involved in Met Signaling in B Cells and Mediates Hepatocyte Growth Factor-Induced Receptor Ubiquitination. J Immunol. 2002;169:3793-3800.

49 Lassus P, Janer J, Haglund C, Karikoski R, Andersson LC, Andersson S. Consistent expression of HGF Birchmeier C, Gherardi E. Developmental roles of HGF/SF and its receptor, the c-met tyrosine kinase. Trends Cell Biol. 1998;8:404-410.

50 Tamagnone L, Comoglio PM. Control of invasive growth by hepatocyte growth factor (HGF) and and c-met in the perinatal lung. Biol Neonate. 2006;90:28-33.

51 Comoglio PM, Trusolino L. Invasive growth: from development to metastasis. J Clin Invest. related scatter factors. Cytokine Growth Factor Rev. 1997;8:129-142.

52 Schmidt C, Bladt F, Goedecke S, Brinkmann V, Zschiesche W, Sharpe M, et al. Scatter 2002;109:857-862.

53 Bladt F, Riethmacher D, Isenmann S, Aguzzi A, Birchmeier C. Essential role for the c-met receptor in factor/hepatocyte growth factor is essential for liver development. Nature. 1995;373:699-702.

54 Maina F, Hilton MC, Andres R, Wyatt S, Klein R, Davies AM. Multiple roles for hepatocyte growth the migration of myogenic precursor cells into the limb bud. Nature. 1995;376:768-771.

55 Sonnenberg E, Meyer D, Weidner KM, Birchmeier C. Scatter factor/hepatocyte growth factor and its receptor, the c-met tyrosine kinase, can mediate a signal exchange between mesenchyme and epithelia during mouse development. J Cell Biol. 1993;123:223-235.

Zhang Y-W, Su Y, Volpert O V, Woude GF V. Hepatocyte growth factor/scatter factor mediates angiogenesis through positive VEGF and negative thrombospondin 1 regulation. Proc Natl Acad Sci. 2003;100:12718-12723.

57 Mujtaba G, Schultz JM, Imtiaz A, Morell RJ, Friedman TB, Naz S. A mutation of MET, encoding hepatocyte growth factor receptor, is associated with human DFNB97 hearing loss. J Med Genet. 2015;52:548-552.

58 Borowiak M, Garratt AN, Wustefeld T, Strehle M, Trautwein C, Birchmeier C. Met provides essential signals for liver regeneration. Proc Natl Acad Sci. 2004;101:10608-10613.

59 Matsumoto K, Nakamura T. Hepatocyte growth factor: Renotropic role and potential therapeutics for renal diseases. Kidney Int. 2001;59:2023-2038.

60 Grano M, Galimi F, Zambonin G, Colucci S, Cottone E, Zallone AZ, et al. Hepatocyte growth factor is a coupling factor for osteoclasts and osteoblasts in vitro. Proc Natl Acad Sci. 1996;93:7644-7648.

61 Nakamura T, Mizuno S, Matsumoto K, Sawa Y, Matsuda H, Nakamura T. Myocardial protection from ischemia/reperfusion injury by endogenous and exogenous HGF. J Clin Invest. 2000;106:1511- 
1519.

Soman NR, Correa P, Ruiz BA, Wogan GN. The TPR-MET oncogenic rearrangement is present and expressed in human gastric carcinoma and precursor lesions. Proc Natl Acad Sci U S A. 1991;88:4892-4896.

63 Matsumoto K, Nakamura T. Hepatocyte growth factor and the Met system as a mediator of tumorstromal interactions. Int J Cancer. 2006;119:477-483.

64 Park M, Park H, Kim WH, Cho H, Lee JH. Presence of autocrine hepatocyte growth factor-Met signaling and its role in proliferation and migration of SNU-484 gastric cancer cell line. Exp Mol Med. 2005;37:213-219.

65 Yi S, Tsao M-S. Activation of Hepatocyte Growth Factor-Met Autocrine Loop Enhances Tumorigenicity in a Human Lung Adenocarcinoma Cell Line. Neoplasia. 2000;2:226-234.

66 Di Renzo MF, Olivero M, Giacomini A, Porte H, Chastre E, Mirossay L, et al. Overexpression and amplification of the met/HGF receptor gene during the progression of colorectal cancer. Clin Cancer Res. 1995;1:147-154.

67 Di Renzo MF, Olivero M, Katsaros D, Crepaldi T, Gaglia P, Zola P, et al. Overexpression of the Met/HGF receptor in ovarian cancer. Int J Cancer. 1994;58:658-662.

68 Lengyel E, Prechtel D, Resau JH, Gauger K, Welk A, Lindemann K, et al. c-Met overexpression in node-positive breast cancer identifies patients with poor clinical outcome independent of Her2/neu. Int J Cancer. 2005;113:678-682.

69 Nakamura Y, Matsubara D, Goto A, Ota S, Sachiko O, Ishikawa S, et al. Constitutive activation of cMet is correlated with c-Met overexpression and dependent on cell-matrix adhesion in lung adenocarcinoma cell lines. Cancer Sci. 2008;99:14-22.

70 Furukawa T, Duguid WP, Kobari M, Matsuno S, Tsao MS. Hepatocyte growth factor and Met receptor expression in human pancreatic carcinogenesis. Am J Pathol. 1995;147:889-895.

71 Di Renzo MF, Olivero M, Serini G, Orlandi F, Pilotti S, Belfiore A, et al. Overexpression of the CMET/HGF receptor in human thyroid carcinomas derived from the follicular epithelium. J Endocrinol Invest. 1995;18:134-139.

72 Kitajima Y, Ide T, Ohtsuka T, Miyazaki K. Induction of hepatocyte growth factor activator gene expression under hypoxia activates the hepatocyte growth factor/c-Met system via hypoxia inducible factor-1 in pancreatic cancer. Cancer Sci. 2008;99:1341-1347.

73 De Bacco F, Luraghi P, Medico E, Reato G, Girolami F, Perera T, et al. Induction of MET by ionizing radiation and its role in radioresistance and invasive growth of cancer. J Natl Cancer Inst. 2011;103:645-661.

74 Ivan M, Bond JA, Prat M, Comoglio PM, Wynford-Thomas D. Activated ras and ret oncogenes induce over-expression of c-met (hepatocyte growth factor receptor) in human thyroid epithelial cells. Oncogene. 1997;14:2417-2423.

75 Houldsworth J, Cordon-Cardo C, Ladanyi M, Kelsen DP, Chaganti RSK. Gene Amplification in Gastric and Esophageal Adenocarcinomas. Cancer Res. 1990;50:6417-6422. 
Hara T, Ooi A, Kobayashi M, Mai M, Yanagihara K, Nakanishi I. Amplification of c-myc, K-sam, and c-met in gastric cancers: detection by fluorescence in situ hybridization. Lab Invest. 1998;78:11431153.

77 Di Renzo MF, Poulsom R, Olivero M, Comoglio PM, Lemoine NR. Expression of the Met/Hepatocyte Growth Factor Receptor in Human Pancreatic Cancer. Cancer Res. 1995;55:1129-1138.

78 Tong CYK, Hui ABY, Yin X-L, Pang JCS, Zhu X-L, Poon W-S, et al. Detection of oncogene amplifications in medulloblastomas by comparative genomic hybridization and array-based comparative genomic hybridization. J Neurosurg. 2004;100:187-193.

Bean J, Brennan C, Shih J-Y, Riely G, Viale A, Wang L, et al. MET amplification occurs with or without T790M mutations in EGFR mutant lung tumors with acquired resistance to gefitinib or erlotinib. Proc Natl Acad Sci. 2007;104:20932-20937.

80 Comoglio PM, Giordano S, Trusolino L. Drug development of MET inhibitors: Targeting oncogene addiction and expedience. Nat Rev Drug Discov. 2008;7:504-516.

81 Di Renzo MF, Olivero M, Martone T, Maffe A, Maggiora P, De Stefani A, et al. Somatic mutations of the MET oncogene are selected during metastatic spread of human HNSC carcinomas. Oncogene. 2000;19:1547-1555.

82 Schmidt L, Junker K, Nakaigawa N, Kinjerski T, Weirich G, Miller M, et al. Novel mutations of the MET proto-oncogene in papillary renal carcinomas. Oncogene. 1999;18:2343-2350.

83 Lee J-H, Han S-U, Cho H, Jennings B, Gerrard B, Dean M, et al. A novel germ line juxtamembrane Met mutation in human gastric cancer. Oncogene. 2000;19:4947-4953.

84 Medová M, Pochon B, Streit B, Blank-Liss W, Francica P, Stroka D, et al. The novel ATP-competitive inhibitor of the MET hepatocyte growth factor receptor EMD1214063 displays inhibitory activity against selected MET-mutated variants. Mol Cancer Ther. 2013;12:2415-2424.

85 Rusciano D, Lorenzoni P, Burger MM. Constitutive activation of c-Met in liver metastatic B16 melanoma cells depends on both substrate adhesion and cell density and is regulated by a cytosolic tyrosine phosphatase activity. J Biol Chem. 1996;271:20763-20769.

86 Frampton GM, Ali SM, Rosenzweig M, Chmielecki J, Lu X, Bauer TM, et al. Activation of MET via diverse exon 14 splicing alterations occurs in multiple tumor types and confers clinical sensitivity to MET inhibitors. Cancer Discov. 2015;5:850-859.

87 Pilotto S, Gkountakos A, Carbognin L, Scarpa A, Tortora G, Bria E. MET exon 14 juxtamembrane splicing mutations: clinical and therapeutical perspectives for cancer therapy. Ann Transl Med. 2017;5:2-2.

88 Breindel JL, Haskins JW, Cowell EP, Zhao M, Nguyen DX, Stern DF. EGF Receptor Activates MET through MAPK to Enhance Non-Small Cell Lung Carcinoma Invasion and Brain Metastasis. Cancer Res. 2013;73:5053-5065.

89 Follenzi A, Bakovic S, Gual P, Stella MC, Longati P, Comoglio PM. Cross-talk between the protooncogenes Met and Ron. Oncogene. 2000;19:3041-3049.

90 Bauer TW, Somcio RJ, Fan F, Liu W, Johnson M, Lesslie DP, et al. Regulatory role of c-Met in insulin- 
like growth factor-I receptor-mediated migration and invasion of human pancreatic carcinoma cells. Mol Cancer Ther. 2006;5:1676-1682.

91 Salian-Mehta S, Xu M, Wierman ME. AXL and MET crosstalk to promote gonadotropin releasing hormone (GnRH) neuronal cell migration and survival. Mol Cell Endocrinol. 2013;374:92-100.

92 Birchmeier C, Birchmeier W, Gherardi E, Vande Woude GF. Met, metastasis, motility and more. Nat Rev Mol Cell Biol. 2003;4:915-925.

93 Di Renzo MF, Olivero M, Ferro S, Prat M, Bongarzone I, Pilotti S, et al. Overexpression of the cMET/HGF receptor gene in human thyroid carcinomas. Oncogene. 1992;7:2549-2553.

94 Al-Saad S, Richardsen E, Kilvaer TK, Donnem T, Andersen S, Khanehkenari M, et al. The impact of MET, IGF-1, IGF1R expression and EGFR mutations on survival of patients with non-small-cell lung cancer. PLoS One. 2017;12:1-20.

95 Takeuchi H, Bilchik A, Saha S, Turner R, Wiese D, Tanaka M, et al. c-met expression level in primary colon cancer: A predictor of tumor invasion and lymph node metastases. Clin Cancer Res. 2003;9:1480-1488.

96 El-Deiry WS, Vijayvergia N, Xiu J, Scicchitano A, Lim B, Yee NS, et al. Molecular profiling of 6,892 colorectal cancer samples suggests different possible treatment options specific to metastatic sites. Cancer Biol Ther. 2015;16:1726-1737.

97 Kammula US, Kuntz EJ, Francone TD, Zeng Z, Shia J, Landmann RG, et al. Molecular co-expression of the c-Met oncogene and hepatocyte growth factor in primary colon cancer predicts tumor stage and clinical outcome. Cancer Lett. 2007;248:219-228.

98 Park WS, Oh RR, Kim YS, Park JY, Shin MS, Lee HK, et al. Absence of mutations in the kinase domain of the Met gene and frequent expression of Met and HGF/SF protein in primary gastric carcinomas. Apmis. 2000;108:195-200.

99 Zhao J, Zhang X, Xin Y. Up-regulated expression of Ezrin and c-Met proteins are related to the metastasis and prognosis of gastric carcinomas. Histol Histopathol. 2011;26:1111-1120.

100 Sun Y lai, Liu W dong, Ma G yuan, Gao D wei, Jiang Y zhu, Liu Q, et al. Expression of HGF and Met in human tissues of colorectal cancers: biological and clinical implications for synchronous liver metastasis. Int J Med Sci. 2013;10:548-559.

101 Rong S, Segal S, Anver M, Resau JH, Vande Woude GF. Invasiveness and metastasis of NIH 3T3 cells induced by Met-hepatocyte growth factor/scatter factor autocrine stimulation. Proc Natl Acad Sci. 1994;91:4731-4735.

102 Zou HY, Li Q, Lee JH, Arango ME, McDonnell SR, Yamazaki S, et al. An orally available small-molecule inhibitor of c-Met, PF-2341066, exhibits cytoreductive antitumor efficacy through antiproliferative and antiangiogenic mechanisms. Cancer Res. 2007;67:4408-4417.

103 Smolen GA, Sordella R, Muir B, Mohapatra G, Barmettler A, Archibald H, et al. Amplification of MET may identify a subset of cancers with extreme sensitivity to the selective tyrosine kinase inhibitor PHA-665752. Proc Natl Acad Sci. 2006;103:2316-2321.

104 Liu Y, Yu XF, Zou J, Luo ZH. Prognostic value of c-Met in colorectal cancer: A meta-analysis. World J 
105 Bardelli A, Corso S, Bertotti A, Hobor S, Valtorta E, Siravegna G, et al. Amplification of the MET receptor drives resistance to anti-EGFR therapies in colorectal cancer. Cancer Discov. 2013;3:658673.

106 Turke AB, Zejnullahu K, Wu YL, Song Y, Dias-Santagata D, Lifshits E, et al. Preexistence and Clonal

107 Kong-Beltran M, Seshagiri S, Zha J, Zhu W, Bhawe K, Mendoza N, et al. Somatic mutations lead to

108 Tong JH, Yeung SF, Chan AWH, Chung LY, Chau SL, Lung RWM, et al. MET amplification and exon 14

110 Weinstein IB. Cancer. Addiction to oncogenes--the Achilles heal of cancer. Science. 2002;297:63splice site mutation define unique molecular subgroups of non-small cell lung carcinoma with poor prognosis. Clin Cancer Res. 2016;22:3048-3056.

109 Bradley CA, Salto-Tellez M, Laurent-Puig P, Bardelli A, Rolfo C, Tabernero J, et al. Targeting c-MET in gastrointestinal tumours: Rationale, opportunities and challenges. Nat Rev Clin Oncol. 2017;14:562-576.

111 Jain M, Arvanitis C, Chu K, Dewey W, Leonhardt E, Trinh M, et al. Sustained loss of a neoplastic 64.

112 Chin L, DePinho\# RA, Tam A, Pomerantz J, Wong M, Holash J, et al. Essential role for oncogenic Ras phenotype by brief inactivation of MYC. Science (80- ). 2002;297:102-104.

113 Huettner CS, Zhang P, Van Etten RA, Tenen DG. Reversibility of acute B-cell leukaemia induced by in tumour maintenance. Nature. 1999;400:468-472.

114 Colomer R, Lupu R, Bacus SS, Gelmann EP. erbB-2 antisense oligonucleotides inhibit the proliferation of breast carcinoma cells with erbB-2 oncogene amplification. $\mathrm{Br} J$ Cancer. 1994;70:819-825.

115 Sharma S V., Settleman J. Oncogene addiction: Setting the stage for molecularly targeted cancer therapy. Genes Dev. 2007;21:3214-3231.

116 Hochhaus A, Larson RA, Guilhot F, Radich JP, Branford S, Hughes TP, et al. Long-Term Outcomes of Imatinib Treatment for Chronic Myeloid Leukemia. N Engl J Med. 2017;376:917-927.

117 Vogel CL, Cobleigh MA, Tripathy D, Gutheil JC, Harris LN, Fehrenbacher L, et al. Efficacy and Safety of Trastuzumab as a Single Agent in First-Line Treatment of HER2 -Overexpressing Metastatic Breast Cancer. J Clin Oncol. 2002;20:719-726.

118 Weinstein IB, Joe AK. Mechanisms of Disease: Oncogene addiction - A rationale for molecular targeting in cancer therapy. Nat Clin Pract Oncol. 2006;3:448-457.

119 Mok TS, Wu Y, Thongprasert S, Yang C-H, Chu D-T, Saijo N, et al. Gefitinib or Carboplatin-Paclitaxel in Pulmonary Adenocarcinoma. N Engl J Med. 2009;361:947-957.

120 Mitsudomi T, Morita S, Yatabe Y, Negoro S, Okamoto I, Tsurutani J, et al. Gefitinib versus cisplatin 
plus docetaxel in patients with non-small-cell lung cancer harbouring mutations of the epidermal growth factor receptor (WJTOG3405): an open label, randomised phase 3 trial. Lancet Oncol. 2010;11:121-128.

121 Maemondo M, Inoue A, Kobayashi K, Sugawara S, Oizumi S, Isobe H, et al. Gefitinib or Chemotherapy for Non-Small-Cell Lung Cancer with Mutated EGFR. N Engl J Med. 2010;362:23802388.

122 Rosell R, Carcereny E, Gervais R, Vergnenegre A, Massuti B, Felip E, et al. Erlotinib versus standard chemotherapy as first-line treatment for European patients with advanced EGFR mutation-positive non-small-cell lung cancer (EURTAC): A multicentre, open-label, randomised phase 3 trial. Lancet Oncol. 2012;13:239-246.

123 Pagliarini R, Shao W, Sellers WR. Oncogene addiction: pathways of therapeutic response, resistance, and road maps toward a cure. EMBO Rep. 2015;16:280-296.

124 Fan Q, Specht KM, Zhang C, Goldenberg DD, Shokat KM, Weiss WA. Combinatorial Efficacy Achieved Through Two-Point Blockade within a Signaling Pathway-A Chemical Genetic Approach Cancer research 2003 2003:8930-8938.

125 Sawyers C. Targeted cancer therapy. Nature. 2004;432:294-297.

126 Wang J, Goetsch L, Tucker L, Zhang Q, Gonzalez A, Vaidya KS, et al. Anti-c-Met monoclonal antibody ABT-700 breaks oncogene addiction in tumors with MET amplification. BMC Cancer. 2016;16:1-14.

127 Suryavanshi M, Shah A, Kumar D, Panigrahi MK, Metha A, Batra U. MET Amplification and Response to MET Inhibitors in Stage IV Lung Adenocarcinoma. Oncol Res Treat. 2017;40:198-202.

128 Catenacci DVT, Henderson L, Xiao SY, Patel P, Yauch RL, Hegde P, et al. Durable complete response of metastatic gastric cancer with anti-met therapy followed by resistance at recurrence. Cancer Discov. 2011;1:573-579.

129 Feng Y, Ma PC. Anti-MET targeted therapy has come of age: The first durable complete response with MetMAb in metastatic gastric cancer. Cancer Discov. 2011;1:550-554.

130 Michieli P, Mazzone M, Basilico C, Cavassa S, Sottile A, Naldini L, et al. Targeting the tumor and its microenvironment by a dual-function decoy Met receptor. Cancer Cell. 2004;6:61-73.

131 Atabey N, Gao Y, Yao ZJ, Breckenridge D, Soon L, Soriano J V., et al. Potent Blockade of Hepatocyte Growth Factor-stimulated Cell Motility, Matrix Invasion and Branching Morphogenesis by Antagonists of Grb2 Src Homology 2 Domain Interactions. J Biol Chem. 2001;276:14308-14314.

132 Abounader R, Lal B, Luddy C, Koe G, Davidson B, Rosen EM, et al. In vivo targeting of SF/HGF and Cmet expression via U1snRNA/ribozymes inhibits glioma growth and angiogenesis and promotes apoptosis. FASEB J. 2002;16:108-110.

133 Vigna E, Comoglio PM. Targeting the oncogenic Met receptor by antibodies and gene therapy. Oncogene. 2014;34:1883-1889.

134 Burgess TL, Sun J, Meyer S, Tsuruda TS, Sun J, Elliott G, et al. Biochemical Characterization of AMG 102: A Neutralizing, Fully Human Monoclonal Antibody to Human and Nonhuman Primate Hepatocyte Growth Factor. Mol Cancer Ther. 2010;9:400-409. 
Okamoto W, Okamoto I, Tanaka K, Hatashita E, Yamada Y, Kuwata K, et al. TAK-701, a Humanized Monoclonal Antibody to Hepatocyte Growth Factor, Reverses Gefitinib Resistance Induced by Tumor-Derived HGF in Non-Small Cell Lung Cancer with an EGFR Mutation. Mol Cancer Ther. 2010;9:2785-2792.

137 Kim K, Hur Y, Ryu EK, Rhim JH, Choi CY, Baek CM, et al. A neutralizable epitope is induced on HGF upon its interaction with its receptor cMet. Biochem Biophys Res Commun. 2007;354:115-121.

138 Vosjan MJWD, Vercammen J, Kolkman JA, Stigter-van Walsum M, Revets H, van Dongen GAMS. Nanobodies Targeting the Hepatocyte Growth Factor: Potential New Drugs for Molecular Cancer Therapy. Mol Cancer Ther. 2012;11:1017-1025.

139 van der Horst EH, Chinn L, Wang M, Velilla T, Tran H, Madrona Y, et al. Discovery of Fully Human Anti-MET Monoclonal Antibodies with Antitumor Activity against Colon Cancer Tumor Models In Vivo. Neoplasia. 2009;11:355-IN5.

140 Lee JM, Kim B, Lee SB, Jeong Y, Oh YM, Song YJ, et al. Cbl-independent degradation of Met: Ways to avoid agonism of bivalent met-targeting antibody. Oncogene. 2014;33:34-43.

141 Liu L, Zeng W, Wortinger MA, Yan SB, Cornwell P, Peek VL, et al. LY2875358, a neutralizing and internalizing anti-MET bivalent antibody, inhibits HGF-dependent and HGF-independent MET activation and tumor growth. Clin Cancer Res. 2014;20:6059-6070.

142 Wang J, Anderson MG, Oleksijew A, Vaidya KS, Boghaert ER, Tucker L, et al. ABBV-399, a c-Met antibody-drug conjugate that targets both MET-amplified and c-Met-overexpressing tumors, irrespective of MET pathway dependence. Clin Cancer Res. 2017;23:992-1000.

143 Martens T, Schmidt NO, Eckerich C, Filibrandt R, Merchant M, Schwall R, et al. A novel one-armed anti-c-Met antibody inhibits glioblastoma growth in vivo. Clin Cancer Res. 2006;12:6144-6152.

144 Pacchiana G, Chiriaco C, Stella MC, Petronzelli F, De Santis R, Galluzzo M, et al. Monovalency unleashes the full therapeutic potential of the DN-30 anti-Met antibody. J Biol Chem. 2010;285:36149-36157.

145 Vigna E, Pacchiana G, Chiriaco C, Cignetto S, Fontani L, Michieli P, et al. Targeted therapy by gene transfer of a monovalent antibody fragment against the Met oncogenic receptor. J Mol Med. 2014;92:65-76.

146 Pasquini G, Giaccone G. C-MET inhibitors for advanced non-small cell lung cancer. Expert Opin Investig Drugs. 2018;27:363-375.

147 Basilico C, Pennacchietti S, Vigna E, Chiriaco C, Arena S, Bardelli A, et al. Tivantinib (ARQ197) displays cytotoxic activity that is independent of its ability to bind MET. Clin Cancer Res. 2013;19:2381-2392.

148 Ariyawutyakorn W, Saichaemchan S, Garcia MV. Understanding and targeting MET signaling in solid tumors - are We there yet? J Cancer. 2016;7:633-649.

149 Shaw AT, Ou S-HI, Bang Y-J, Camidge DR, Solomon BJ, Salgia R, et al. Crizotinib in ROS1-rearranged 
non-small-cell lung cancer. N Engl J Med. 2014;371:1963-1971.

944150 Kobayashi T, Fujimoto H, Gabazza EC. Efficacy of crizotinib in ALK fusion variants. J Thorac Dis. 2016;8:E1381-E1383.

151 Rosen PJ, Sweeney CJ, Park DJ, Beaupre DM, Deng H, Leitch IM, et al. A phase Ib study of AMG 102 in combination with bevacizumab or motesanib in patients with advanced solid tumors. Clin Cancer Res. 2010;16:2677-2687.

152 Catenacci DVT, Tebbutt NC, Davidenko I, Murad AM, Al-Batran S-E, Ilson DH, et al. Rilotumumab plus epirubicin, cisplatin, and capecitabine as first-line therapy in advanced MET-positive gastric or gastro-oesophageal junction cancer (RILOMET-1): a randomised, double-blind, placebo-controlled, phase 3 trial. Lancet Oncol. 2017;18:1467-1482.

153 Doi T, Kang Y-K, Muro K, Jiang Y, Jain RK, Lizambri R. A phase 3, multicenter, randomized, doubleblind, placebo-controlled study of rilotumumab in combination with cisplatin and capecitabine (CX) as first-line therapy for Asian patients (pts) with advanced MET-positive gastric or gastroesophageal junction (G. J Clin Oncol. 2015;33:TPS226-TPS226.

154 Shah MA, Bang YJ, Lordick F, Alsina M, Chen M, Hack SP, et al. Effect of fluorouracil, leucovorin, and oxaliplatin with or without onartuzumab in HER2-negative, MET-positive gastroesophageal adenocarcinoma: The METGastric randomized clinical trial. JAMA Oncol. 2017;3:620-627.

155 Spigel DR, Ervin TJ, Ramlau RA, Daniel DB, Goldschmidt JH, Blumenschein GR, et al. Randomized phase II trial of Onartuzumab in combination with erlotinib in patients with advanced non-smallcell lung cancer. J Clin Oncol. 2013;31:4105-4114.

158 Camidge DR, Ou S-HI, Shapiro G, Otterson GA, Villaruz LC, Villalona-Calero MA, et al. Efficacy and safety of crizotinib in patients with advanced c-MET-amplified non-small cell lung cancer (NSCLC).

160 Lennerz JK, Kwak EL, Ackerman A, Michael M, Fox SB, Bergethon K, et al. MET amplification identifies a small and aggressive subgroup of esophagogastric adenocarcinoma with evidence of responsiveness to crizotinib. J Clin Oncol. 2011;29:4803-4810.

161 Van Schaeybroeck S, Rolfo CD, Élez E, Kelly S, Houlden J, Collins L, et al. MErCuRIC1: A Phase I study of MEK1/2 inhibitor PD-0325901 with CMET inhibitor crizotinib in RASMT and RASWT (with aberrant c-MET) metastatic colorectal cancer (mCRC) patients. J Clin Oncol. 2015;33:TPS3632TPS3632. 
982

983

984

985

986

987

988

989

990

991

992

993

994

995

996

997

998

999

1000

1001

1002

1003

1004

1005

1006

1007

1008

1009

1010

1011

1012

1013

1014

1015

1016

1017

1018

1019

16

Cometriq

।

European

Medicines

Agency.

Available

at https://www.ema.europa.eu/en/medicines/human/EPAR/cometriq Accessed January 13, 2019.

163 Cabometyx | European Medicines Agency. Available at https://www.ema.europa.eu/en/medicines/human/EPAR/cabometyx Accessed January 13, 2019.

164 Abou-Alfa GK, Meyer T, Cheng A-L, El-Khoueiry AB, Rimassa L, Ryoo B-Y, et al. Cabozantinib in Patients with Advanced and Progressing Hepatocellular Carcinoma. N Engl J Med. 2018;379:54-63.

165 de Jesus VHF, Dettino ALA. Update on hepatocellular carcinoma from the 2018 Gastrointestinal Cancer Symposium (ASCO GI). J Hepatocell Carcinoma. 2018;5:87-90.

166 Personeni N, Pressiani T, Santoro A, Rimassa L. Regorafenib in hepatocellular carcinoma: Latest evidence and clinical implications. Drugs Context. 2018;7:1-10.

167 Schuler MH, Berardi R, Lim W-T, Geel R Van, De Jonge MJ, Bauer TM, et al. Phase (Ph) I study of the safety and efficacy of the CMET inhibitor capmatinib (INC280) in patients (pts) with advanced cMET+ non-small cell lung cancer (NSCLC). J Clin Oncol. 2016;34:9067.

168 Wu Y-L, Kim D-W, Felip E, Zhang L, Liu X, Zhou CC, et al. Phase (Ph) II safety and efficacy results of a single-arm ph ib/II study of capmatinib (INC280) + gefitinib in patients (pts) with EGFR-mutated (mut), cMET-positive (cMET+) non-small cell lung cancer (NSCLC). J Clin Oncol. 2016;34:9020.

169 Falchook GS, Hong DS, Amin HM, Fu S, Piha-Paul SA, Janku F, et al. Results of the first-in-human phase I trial assessing MSC2156119J (EMD 1214063), an oral selective c-Met inhibitor, in patients (pts) with advanced solid tumors. J Clin Oncol. 2014;32:2521.

170 Qin S, HY L, B-Y R, Li C, Xiong H, Johne A, et al. Phase II trial comparing the oral c-Met inhibitor tepotinib (MSC2156119J) with sorafenib first line in asian patients with advanced HCC. Liver Cancer. 2015.

171 Kim TY, Qin S, Lim HY, Ryoo BY, Li C, Cheng AL. Phase II study of the c-Met inhibitor tepotinib compared with sorafenib as first-line treatment for Asian patients with advanced HCC. Liver Cancer. 2016.

172 Qin S, Lim HY, Ryoo BY, Li C, Xiong H, Ihling C, et al. Data from a phase Ib/II trial of the oral c-Met inhibitor tepotinib (MSC2156119J) as first-line therapy in Asian patients with advanced hepatocellular carcinoma. Eur J Cancer. 2015.

173 Hong DS, LoRusso P, Hamid O, Janku F, Kittaneh M, Catenacci DVT, et al. Phase I Study of AMG 337, a Highly Selective Small-molecule MET Inhibitor, in Patients with Advanced Solid Tumors. Clin Cancer Res. 2019;25:2403-2413.

174 Choueiri TK, Jakacki R, Ghiorghiu D, Haddad V, Kohlmann A, Frigault MM, et al. 924TiPSavolitinib versus sunitinib in patients with MET-driven, unresectable and locally advanced or metastatic papillary renal cell carcinoma: SAVOIR, a randomised, phase III trial. Ann Oncol. 2017;28:v328.

175 Mignot F, Ajgal Z, Xu H, Geraud A, Chen JY, Mégnin-Chanet F, et al. Concurrent administration of anti-HER2 therapy and radiotherapy: Systematic review. Radiother Oncol. 2017;124:190-199.

176 Kohno T, Nakaoku T, Tsuta K, Tsuchihara K, Matsumoto S, Yoh K, et al. Beyond ALK-RET, ROS1 and other oncogene fusions in lung cancer. Transl Lung Cancer Res. 2015;4:156-164. 
177 Watermann I, Schmitt B, Stellmacher F, Müller J, Gaber R, Kugler C, et al. Improved diagnostics targeting c-MET in non-small cell lung cancer: Expression, amplification and activation? Diagn Pathol. 2015;10:1-12.

178 Nakamura Y, Niki T, Goto A, Morikawa T, Miyazawa K, Nakajima J, et al. c-Met activation in lung adenocarcinoma tissues: An immunohistochemical analysis. Cancer Sci. 2007;98:1006-1013.

179 Srivastava AK, Navas T, Herrick WG, Hollingshead MG, Bottaro DP, Doroshow JH, et al. Effective implementation of novel MET pharmacodynamic assays in translational studies. Ann Transl Med. 2017;5:3-3.

180 Huang F, Ma Z, Pollan S, Yuan X, Swartwood S, Gertych A, et al. Quantitative imaging for development of companion diagnostics to drugs targeting HGF/MET. J Pathol Clin Res. 2016;2:210222.

181 Garber K. MET inhibitors start on road to recovery. Nat Rev Drug Discov. 2014;13:563-565.

182 Koeppen H, Yu W, Zha J, Pandita A, Penuel E, Rangell L, et al. Biomarker Analyses from a PlaceboControlled Phase II Study Evaluating Erlotinib Onartuzumab in Advanced Non-Small Cell Lung Cancer: MET Expression Levels Are Predictive of Patient Benefit. Clin Cancer Res. 2014;20:44884498.

183 Collisson EA, Campbell JD, Brooks AN, Berger AH, Lee W, Chmielecki J, et al. Comprehensive molecular profiling of lung adenocarcinoma: The cancer genome atlas research network. Nature. 2014;511:543-550.

184 Miliotou AN, Papadopoulou LC. CAR T-cell Therapy: A New Era in Cancer Immunotherapy. Curr Pharm Biotechnol. 2018;19:5-18.

185 Ahmed N, Salsman VS, Yvon E, Louis CU, Perlaky L, Wels WS, et al. Immunotherapy for osteosarcoma: Genetic modification of T cells overcomes low levels of tumor antigen expression. Mol Ther. 2009;17:1779-1787.

186 Watanabe K, Terakura S, Martens AC, van Meerten T, Uchiyama S, Imai M, et al. Target Antigen Density Governs the Efficacy of Anti-CD20-CD28-CD3 $\zeta$ Chimeric Antigen Receptor-Modified Effector CD8 + T Cells. J Immunol. 2015;194:911-920.

187 Lim WA, June CH. The Principles of Engineering Immune Cells to Treat Cancer. Cell. 2017;168:724740.

188 Feng K, Guo Y, Dai H, Wang Y, Li X, Jia H, et al. Chimeric antigen receptor-modified T cells for the immunotherapy of patients with EGFR-expressing advanced relapsed/refractory non-small cell lung cancer. Sci China Life Sci. 2016;59:468-479.

189 Li N, Liu S, Sun M, Chen W, Xu X, Zeng Z, et al. Chimeric Antigen Receptor-Modified T Cells Redirected to EphA2 for the Immunotherapy of Non-Small Cell Lung Cancer. Transl Oncol. 2018;11:11-17.

190 Ahmed N, Brawley VS, Hegde M, Robertson C, Ghazi A, Gerken C, et al. Human epidermal growth factor receptor 2 (HER2) - Specific chimeric antigen receptor - Modified T cells for the immunotherapy of HER2-positive sarcoma. J Clin Oncol. 2015;33:1688-1696. 
1058

1059

1060

1061

1062

1063

1064

1065

1066

1067

1068

1069

1070

1071

1072

1073

1074

1075

1076

1077

1078

1079

1080

1081

1082

1083

1084

1085

1086

1087

1088

1089

1090

1091

1092

1093

1094

1095
191 Tchou J, Zhao Y, Levine BL, Zhang PJ, Davis MM, Melenhorst JJ, et al. Safety and Efficacy of Intratumoral Injections of Chimeric Antigen Receptor (CAR) T Cells in Metastatic Breast Cancer. Cancer Immunol Res. 2017;5:1152-1161.

192 Thayaparan T, Petrovic RM, Achkova DY, Zabinski T, Davies DM, Klampatsa A, et al. CAR T-cell immunotherapy of MET-expressing malignant mesothelioma. Oncoimmunology. 2017;6:e1363137.

193 Koeppen H, Rost S, Yauch RL. Developing biomarkers to predict benefit from HGF/MET pathway inhibitors. J Pathol. 2014;232:210-218.

194 Miyata Y, Kanetake H, Kanda S. Presence of phosphorylated hepatocyte growth factor receptor/cMet is associated with tumor progression and survival in patients with conventional renal cell carcinoma. Clin Cancer Res. 2006;12:4876-4881.

195 Tretiakova M, Salama AKS, Karrison T, Ferguson MK, Husain AN, Vokes EE, et al. MET and phosphorylated MET as potential biomarkers in lung cancer. J Environ Pathol Toxicol Oncol. 2011;30:341-354.

196 Awad MM, Oxnard GR, Jackman DM, Savukoski DO, Hall D, Shivdasani P, et al. MET exon 14 mutations in Non-small-cell lung cancer are associated with advanced age and stage-dependent MET genomic amplification and c-Met overexpression. J Clin Oncol. 2016;34:721-730.

197 Santini FC, Kunte S, Drilon A. Combination MET- and EGFR-directed therapy in MET-overexpressing non-small cell lung cancers: time to move on to better biomarkers? Transl Lung Cancer Res. 2017;6:393-395.

198 Mcneil BC. NCl-MATCH Launch Highlights New Trial Design in Precision- Medicine Era By Caroline McNeil Genomic Research Advances Pancreatic Cancer' s Early Detection and Treatment 2015;107:7-8.

199 Mullard A. NCl-MATCH trial pushes cancer umbrella trial paradigm. Nat Publ Gr. 2015;14:513-515.

200 Sacher AG, Jänne PA, Oxnard GR. Management of acquired resistance to epidermal growth factor receptor kinase inhibitors in patients with advanced non-small cell lung cancer. Cancer. 2014;120:2289-2298.

201 Jänne PA, Yang JC-H, Kim D-W, Planchard D, Ohe Y, Ramalingam SS, et al. AZD9291 in EGFR inhibitor-resistant non-small-cell lung cancer. N Engl J Med. 2015;372:1689-1699.

202 Ou SHI, Young L, Schrock AB, Johnson A, Klempner SJ, Zhu VW, et al. Emergence of Preexisting MET Y1230C Mutation as a Resistance Mechanism to Crizotinib in NSCLC with MET Exon 14 Skipping. J Thorac Oncol. 2017;12:137-140.

203 Engstrom LD, Aranda R, Lee M, Tovar EA, Essenburg CJ, Madaj Z, et al. Glesatinib exhibits antitumor activity in lung cancer models and patients harboring MET exon 14 mutations and overcomes mutation-mediated resistance to type I MET inhibitors in nonclinical models. Clin Cancer Res. 2017;23:6661-6672.

204 Bahcall M, Sim T, Paweletz CP, Patel JD, Alden RS, Kuang Y, et al. Acquired METD1228V Mutation and Resistance to MET Inhibition in Lung Cancer. Cancer Discov. 2016;6:1334-1341. 
1096205 Kwak EL, Ahronian LG, Siravegna G, Mussolin B, Godfrey JT, Clark JW, et al. Molecular heterogeneity and receptor coamplification drive resistance to targeted therapy in MET-Amplified esophagogastric cancer. Cancer Discov. 2015;5:1271-1281.

1099206 Du J, Wu X, Tong X, Wang X, Wei J, Yang Y, et al. Circulating tumor DNA profiling by next generation 1100 sequencing reveals heterogeneity of crizotinib resistance mechanisms in a gastric cancer patient $1101 \quad$ with MET amplification. Oncotarget. 2017;8:26281-26287.

1102207 Kuba K, Matsumoto K, Date K, Shimura H, Tanaka M, Nakamura T. HGF/NK4, a four-kringle 1103 antagonist of hepatocyte growth factor, is an angiogenesis inhibitor that suppresses tumor growth and metastasis in mice. Cancer Res. 2000;60:6737-6743.

1105208 Lu K V., Chang JP, Parachoniak CA, Pandika MM, Aghi MK, Meyronet D, et al. VEGF Inhibits Tumor 1106 Cell Invasion and Mesenchymal Transition through a MET/VEGFR2 Complex. Cancer Cell. 1107 2012;22:21-35.

1108209 Cerami E, Gao J, Dogrusoz U, Gross BE, Sumer SO, Aksoy BA, et al. The cBio Cancer Genomics Portal: 1109 An open platform for exploring multidimensional cancer genomics data. Cancer Discov. 2012;2:401-404.

1111210 Gao J, Aksoy BA, Dogrusoz U, Dresdner G, Gross B, Sumer SO, et al. Integrative analysis of complex 1112 cancer genomics and clinical profiles using the cBioPortal. Sci Signal. 2013;6. 


\section{Figure and Table legends}

1115 Figure 1. Schematic representation of the subunits, domains and known phosphorylation sites of MET and

1116 HGF, as well as major signaling pathways downstream of MET.

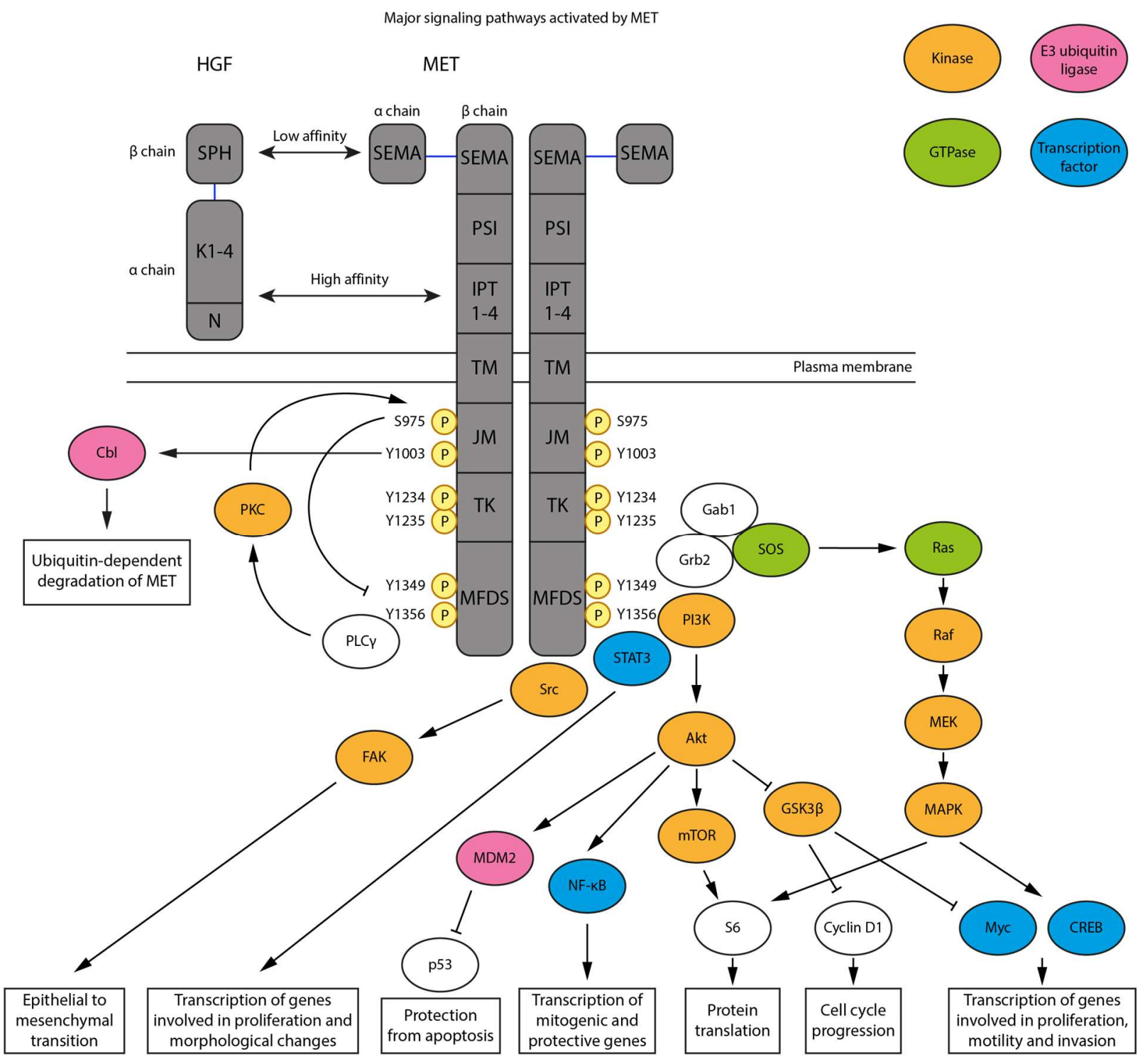

1117

1118

1119 
1120 Figure 2. Summary of MET alterations frequency and outcome in different cancer types. Visualization of 1121 the data generated on cBioportal.org [209,210] from 212 studies (see link for detailed list:

1122 https://www.cbioportal.org/results/cancerTypesSummary?session_id=5d78f196e4b058f36688adc1, last

1123 accessed on the $11^{\text {th }}$ of September 2019)

1124 A. Frequency of MET genetic alterations in various cancer studies (studies with an alteration frequency

1125 lower than $1 \%$ have been excluded from the graph).

1126 B. MET RNA expression in various types of cancer.

1127 C. Kaplan-Meier graphs showing overall progression-free survival of cancer cases with and without $1128 \quad$ MET alterations.

(a)

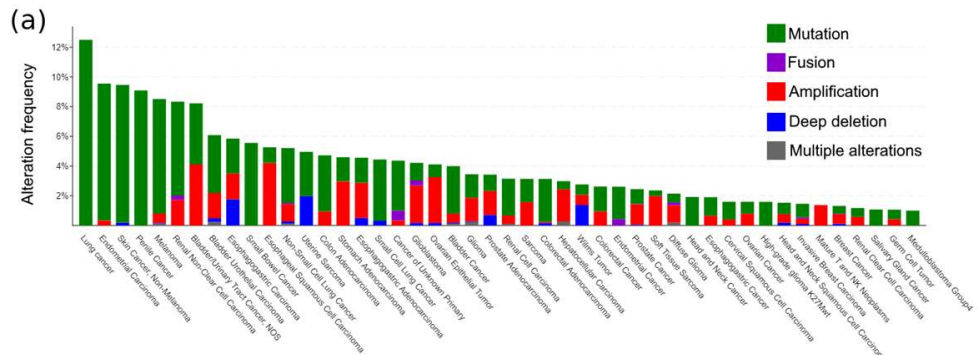

(10)

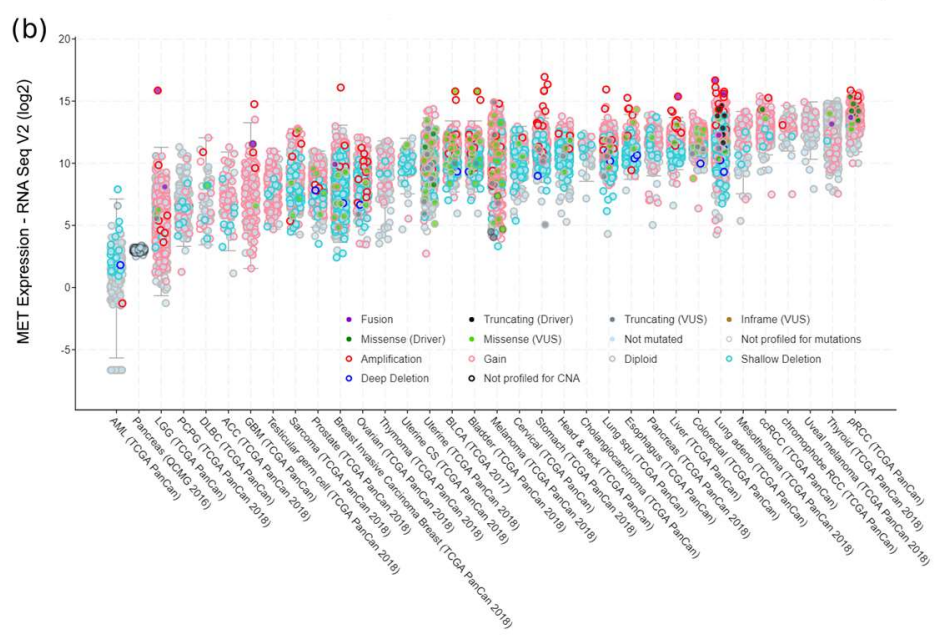

(c)

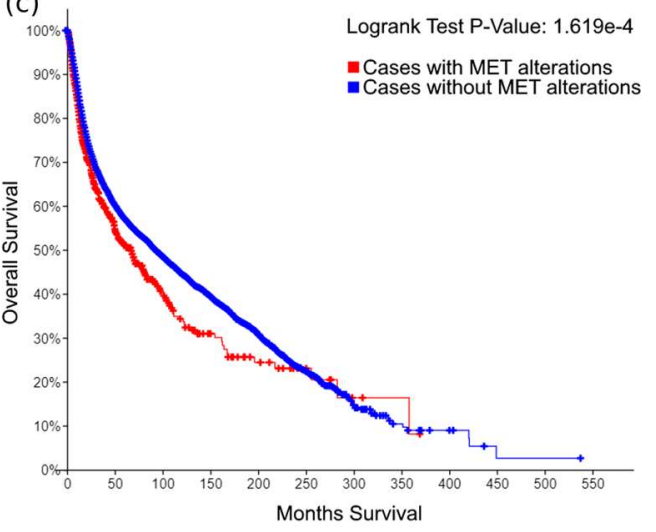


1132 Table 1. Summary of MET inhibitors in use and in development. 


\begin{tabular}{|c|c|c|}
\hline Compound name & Company & Targeted kinase(s) \\
\hline Crizotinib (PF-02341066) & $\begin{array}{l}\text { Pfizer (New York City, } \\
\text { New York, USA) }\end{array}$ & MET, ALK, RON, AXL, TIE2, ROS1 \\
\hline Cabozantinib (XL184) & $\begin{array}{l}\text { Exelixis (Alameda, } \\
\text { California, USA) }\end{array}$ & $\begin{array}{l}\text { MET, RET, VEGFR1-3, KIT, FLT3, } \\
\text { TIE2, TRKB, AXL }\end{array}$ \\
\hline Foretinib (XL880) & $\begin{array}{l}\text { Exelixis/GlaxoSmithKline } \\
\text { (London, UK) }\end{array}$ & $\begin{array}{l}\text { MET, VEGFR2, RON, ERK, AKT, } \\
\text { PDGFR } \beta, \text { c-KIT, TIE2 }\end{array}$ \\
\hline Glesatinib (MGCD265) & $\begin{array}{l}\text { MethylGene/Mirati } \\
\text { Therapeutics (San Diego, } \\
\text { California, USA) }\end{array}$ & $\begin{array}{l}\text { MET, RON, VEGFR1-2, PDGFR, KIT, } \\
\text { FLT3, TIE2, AXL }\end{array}$ \\
\hline Golvatinib (E-7050) & Eisai (Tokyo, Japan) & MET, VEGFR2, RON, Eph, KIT \\
\hline Merestinib (LY2801653) & Eli Lilly & $\begin{array}{l}\text { MET, MST1R, FLT3, AXL, MERTK, } \\
\text { TIE2, ROS1, NTRK1/2/3, DDR1/2, } \\
\text { MKNK1/2, VEGFR2 }\end{array}$ \\
\hline PF-04217903 & Pfizer & MET, ALK \\
\hline AMG 208 & Amgen & MET, VEGFR1-3, RON, TIE2 \\
\hline $\begin{array}{l}\text { Capmatinib } \\
(\text { INC280/INCB28060) }\end{array}$ & $\begin{array}{l}\text { Incyte (Wilmington, } \\
\text { Delaware, USA)/Novartis } \\
\text { (Basel, Switzerland) }\end{array}$ & MET \\
\hline Tepotinib (EMD1214063) & $\begin{array}{l}\text { EMD Serono (Darmstadt, } \\
\text { Germany) }\end{array}$ & MET \\
\hline AMG 337 & Amgen & MET \\
\hline $\begin{array}{l}\text { Savolitinib/Volitinib } \\
\text { (AZD6094) }\end{array}$ & $\begin{array}{l}\text { AstraZeneca (Cambridge, } \\
\text { UK) }\end{array}$ & MET \\
\hline
\end{tabular}


OMO-1 (JNJ-38877618) Johnson \& Johnson (New ME

Brunswick, New Jersey,

USA)

1133 